Article

\title{
Preserving Community's Environmental Interests in a Meta-Ocean Governance Framework towards Sustainable Development Goal 14: A Mechanism of Promoting Coordination between Institutions Responsible for Curbing Marine Pollution
}

\author{
Khadija Zulfiqar (D) and M Jahanzeb Butt *(D) \\ School of Law, Dalian Maritime University, Dalian 116026, China; khadijazulfiqar@gmail.com \\ * Correspondence: jahanzeb.buic@bahria.edu.pk; Tel.: +86-155-2481-3853
}

Citation: Zulfiqar, K.; Butt, M.J.

Preserving Community's

Environmental Interests in a

Meta-Ocean Governance Framework

towards Sustainable Development

Goal 14: A Mechanism of Promoting

Coordination between Institutions

Responsible for Curbing Marine

Pollution. Sustainability 2021, 13, 9983.

https://doi.org/10.3390/su13179983

Academic Editors: Keyuan Zou and Yen-Chiang Chang

Received: 1 July 2021

Accepted: 3 September 2021

Published: 6 September 2021

Publisher's Note: MDPI stays neutral with regard to jurisdictional claims in published maps and institutional affiliations.

Copyright: (c) 2021 by the authors. Licensee MDPI, Basel, Switzerland. This article is an open access article distributed under the terms and conditions of the Creative Commons Attribution (CC BY) license (https:// creativecommons.org/licenses/by/ $4.0 /)$.
Abstract: The United Nations has recently recognised the global community's environmental interests in ocean governance through the Sustainable Development Goal 14. The marine environmental protection targets stand in need of rejuvenating international environmental law, which fosters interconnection between oceans, climate, and terrestrial ecosystems. The existing literature on this aspect of ocean governance, however, is segregated and lacks an ecosystem-based approach. Therefore, a comprehensive review of the literature on ocean governance with an ecosystem-based approach becomes essential and is conducted through this research. This research has proposed that ocean governance programmes and plans need to be re-arranged under established legal frameworks at national and regional levels. Such a challenge can be addressed by taking the elements of governance provided by the list of targets of sustainable development goals. This research has facilitated the given hypothesis via a meta-ocean-governance framework that incorporates a deliberate regional monitoring system, intergovernmental review, capacity building techniques, national action through strong institutions, scientific decision making, and policy coherence. The idea is to fit the conceptualisation of ocean governance under international environmental law in the existing initiatives within a box of institutions to coordinate and encourage an ecosystembased approach.

Keywords: ocean governance; sustainable development goals (SDGs); SDG 14; marine environment; international environmental law; Law of the Sea; ocean acidification; rising-sea-levels; meta-governance; ocean action

\section{Introduction}

In 2018, the United Nations (UN) launched a formal intergovernmental consultation about a proposed global environmental treaty under the principles set forth the rights of erga omnes (towards all) and ius cogens (compelling law) to a healthy environment [1]. The right to a healthy environment with the principles of erga omnes and ius cogens was also recognised by the Inter-American Court of Human Rights in its recent advisory opinion [1]. The Republic of Colombia referred to this advisory opinion during a consultation session under the Cartagena Agreement (Convention on the Protection and Development of the Marine Environment in the Wider Caribbean Region) in the UN. The panel's experts interpreted and elaborated the fundamental general obligation outlined in the United Nations Convention on the Law of the Sea (UNCLOS), recognising the principles of erga omnes and ius cogens for oceans ecosystems [2,3]. As the UNCLOS and its associated International Environmental Law (IEL) is the compelling law (ius cogens), oceans are considered as the common heritage of mankind (erga omnes) [4]. This purports that fisheries, 
marine ecosystems, international trade, leisure, and ocean resources are shared interests of the global community.

From both historical and contemporary perspectives, a single global ocean is geopolitically divided and recognised as a common interest of the global community [5]. Preservation of the ocean ecosystems is essential for human civilisation and future generations. The principles of erga omnes and ius cogens for oceans ecosystems depict that the global community is putting forth the vision of integrated, holistic, and spatial governance. Previously, in protecting the global community's interests through effective implementation of the law, more comprehensive cross-border actions for preserving ocean ecosystems were established after developing the regional-multilateral environmental agreements (MEAs) under the auspices of the UNCLOS [6]. Similarly, since the promulgation of the United Nations Conference Declaration on Environment and Development (Rio Declaration), many states adopted integrated policies and strategies of ocean governance under Chapter 17 of Agenda 21 [7,8]. With the Sustainable Development Goals (SDGs) emergence, the updated community's interests in ocean governance were submitted under an integrated Sustainable Development Goal 14 to preserve life below water (SDG 14) [9].

SDG 14 intersects almost all the SDGs because life below water is an essential part of the global ecosystems and requires conservation and restoration of terrestrial and atmospheric environments [10]. While recognising the shared competence over the oceans, SDG 14 depicts that most marine pollution emerges from land-based activities (SDG 6 Clean Water and Sanitation and SDG 11 Sustainable Cities and Communities), and the climate crisis (SDG 13 Climate Action) is devastatingly impacting marine ecosystems [11]. Thus, SDG 14 is an environmental goal with the most critical and enduring target of preserving the community's environmental interests. In order to achieve the given targets, SDG 14 underpins compelling (international) law for collaboration among and between the international, regional, and national institutions for the global governance of one common ocean [12]. Therefore, from a comprehensive view, ocean governance under SDG 14 calls for a complex mechanism of coordination/adaptation at various levels and requires the elements driven by SDGs 16 (peace, justice, and strong institution) and SDG 17 (Partnerships for Goals) [13].

Based on the aforesaid, the literature related to ocean governance from ecosystem perspectives significantly deals with the interconnections among marine environment, land-based sources of pollution, and climate change [14,15]. Furthermore, the emerging literature on SDG 14 suggests several prospects of integrating ocean governance with atmospheric and terrestrial environmental governance involving regional and international organisations based on the old architecture [16]. However, notwithstanding the complexities related to the implementation of SDG 14 with an ecosystem-based approach, much of the up-to-date academic literature has focused on marine environmental protection through ocean governance under soft law [17]. Moreover, the geopolitical influence of the states with interests in marine spaces is not highlighted to explain the fragmentation issues, which is the major cause behind the failure of ecosystem-based approach in ocean governance [18]. Reasons for these relative paucities in describing the ocean governance with geopolitical influence and under SDGs is perhaps their informal recognition. Moreover, the literature focusing on ocean governance under soft law argues that UNCLOS and IEL helped design the plans and programmes for marine environmental protection [17]. Nevertheless, a precise impact on ocean governance has been discussed in a limited fashion because the emergence of SDG 14 has revealed that marine environmental protection still lacks a comprehensive ecosystem-based approach at various levels.

The ecosystem-based approach in governance generally is rationalised through SDG 16 and 17 (SDGs for meta-governance), with the elements fostering cooperation and coordination [19]. The rational application of the elements of SDGs for meta-governance provides detailed prescriptions and a comprehensive approach considering specific ecosystems placed under ocean governance [20]. This research aims to analyse the gaps and disparities among various ocean governance mechanisms at different levels through a methodology 
of comprehensive literature review (CLR). This CLR synthesises the literature that has been published regarding the elements of adaptation of ocean governance with atmospheric and terrestrial environmental governance under the UNCLOS, IEL, and soft law declarations. Consequently, this CLR aims to and will drive marine environmental protection targets of SDG 14 through a governance framework that proposes specific mechanisms of adaptation among and between international, regional, and national ocean governance mechanisms.

\section{SDG 14 and Ocean Governance}

Before comprehensively analysing the literature on ocean governance, it is pertinent to understand the role of SDG 14 in developing the future of ocean governance. SDG 14 primarily aims for healthy and productive ecosystems to sustain the services of oceans and focuses on "planetary health" to preserve the global community's environmental interests [21]. As oceans are the most critical ecosystem in the earth's environment, they produce oxygen, perform critical processes in the hydrological cycle, and preserve marine life [22]. The climate crisis has recently thrown into sharp focus the importance of depleting marine ecosystems and linking it with human health. Certainly, emissions cause devastating impacts on marine life and trigger ocean warming, sea-level rise, acidification, de-oxygenation, and disposal of wastes into the oceans create significant problems for the fisheries and the well-being of fishers [23]. The requirement here is to take a broader approach for SDG 14 and form adaptations in diverse ecosystem governance through a transparent and accountable mechanism. Such an approach shall create a multilevel system of governance capable of developing coordination among and between the institutions governing diverse but common ecosystems [10,24].

It should be noted that the concept of ocean governance is not easy to pin down, and with the evolvement of SDG 14, the concept has become more complex. As ocean governance under SDG 14 is a long-term agenda accompanied by regulations for interactions between the institutions, the policy relates to guidelines and objectives [25]. The reference to IEL and precisely to the UNCLOS in the achievement of SDG 14 requires improvement and harmonisation in policies and programmes within the existing legal frameworks by considering the current and future challenges. Although there are institutional frameworks of ocean governance, they are organically assembled to form a network of self-arranging patterns [26]. Such organic arrangement characterised as polycentricity contains multiple governing institutions rather than a monocentric system. The polycentric arrangements for ocean governance are flexible because they operate with a general legal framework under UNCLOS and IEL [27]. The existing arrangements suggest that when examining the opportunities to improve ocean governance for SDG 14, the inherent polycentricity is viable.

The polycentric systems of ocean governance are mainly developed after establishing various regional MEAs and national ocean policies reinvigorating UNCLOS and IEL under the Rio Declaration [28]. The regional MEAs for ocean governance are the secondtier instruments for inter-state coordination and harmonise the horizontal and vertical coordination among relevant national institutions [29]. The main problem with the regional MEAs is the weak hierarchal mechanism of coordination, i.e., bottom-up integration with global institutions and top-down integration with local institutions. Another cause behind such poor ocean governance at regional levels is the political interests of the states, which also causes fragmentation in national mechanisms [30,31]. Moreover, although the existing legal frameworks for oceans in various states are sustainable, there exists an intersectoral approach due to weak oversight and ineffective monitoring. Such lack of integration has caused a typical failure that lacks structure and reliability at regional levels, inflexibility, and inadequate governance procedures at national levels.

It can be argued, and it is argued, that regional MEAs, UNCLOS, and IEL should be redesigned considering the interconnectedness of ocean governance [32]. However, the conduct of this CLR remains quite pragmatic and, without idealism, prefers that the regional MEAs under existing UNCLOS and IEL are vital for ocean governance and can fix 
the problems of fragmentation at the national levels. The challenge in implementing SDG 14 is not legal; it is a multilevel governance task, and the challenges are different at each level, and regional MEAs are capable of promoting adaptation and ecosystem integration [33]. The fragmentation at national levels is due to differentiated governance of environmental commons, and under existing national policies, the oceans as one of the commons can be responded through the principle of "common but differentiated governance" (CBDG) [34]. Therefore, it is essential to convert polycentricity into adaptation to fix the multilevel ocean governance by formalising the existing patterns rather than devising new policies.

\section{Comprehensive Literature Review}

\subsection{Methodology}

This CLR aims to reveal the existing state of the academic acumen in ocean governance and, for this purpose, has followed the sustainable development interpretation methodology (SDIM) [35]. As required, the basis of this CLR is driven by the theory of "reconceptualization of institutional coordination and environmental interconnectedness in governance" $[36,37]$. This theory is core phenomena of SDGs and Anthropocene, which interlinks diverse ecosystems under earth system governance and shall provide effective means of interlinking the marine environmental protection with atmospheric and terrestrial environmental governance (as provided in Figure 1) [13]. Therefore, the articles were selected, emphasising the elements of interdependence and interconnectedness among and between national (inter-sectoral and hierarchal), regional, and international ocean governing institutions. The search criteria for the articles were based on the combinations of search terms, namely "ocean governance + climate, water, sanitation, and waste", and "oceans + SDGs and SDG 14" are used for data extraction. Initially, the search criteria produced plenty of articles; after selecting the articles on law and institutions, environmental diplomacy, and geopolitics of international, regional, and national ocean governance, the articles fostering cooperation and coordination were discussed and analysed, reported on below.

\section{THEORY DRIVEN} SDG 14

Theory of institutional coordination and environmental interconnectedness

Conceptual reviews to formalise the institutional approach for coordination to marine environmental governance from its current international, regional, and national domains [36,37].

\section{SYSTEMATIC CRITERIA OF SEARCH AND EXTRACTION}

1. Ocean Governance

2. UNCLOS and IEL

3. Sustainable Development Goals

\section{Significant interconnections} among the law of marine environmental protection and the international environmental treaties and declarations for atmospheric and terrestrial environments [38-40].

\section{APPLICATION OF A QUALITY FRAMEWORK FOR INTERPRETATION}

\author{
Meta-Governance \\ Framework
}

Elements provided by the SDGs

16 and 17 for meta-governance

$$
\text { in providing significant }
$$
measures in

resolving the marine pollution from land-based sources and climate change impacts $[13,14,41]$.

Figure 1. Sustainable Development Interpretation (CLR) Methodology [13,14,36-41].

To better understand the existing mechanisms of ocean governance, a simple step-bystep approach was adopted, starting with mapping the global and regional mechanisms, conducting critical analysis, and defining the challenges at various levels. Few and good 
examples from regional initiatives and national plans were discussed in order to keep the CLR within the customisation limits. The explored literature on regional and national ocean governance practices with the elements provides that implementation exists but with weak coordination. Therefore, the discussion following the analysis put planning options in place with adaptation elements and by formalising SDGs for meta-governance applicable on oceans.

\subsection{Early Decades of Environmental Diplomacy and Its Impacts on Global Ocean Governance}

The geopolitical interests of the states and the influence of large and dominant coastal states have caused the institutional challenges to form ecosystem ocean governance approaches at the global level [42]. This is evident from the Rio Declaration, which was negotiated by the Conference for Parties (COP) two decades after the Declaration of the United Nations Conference on Human Environment (Stockholm Declaration) urged to form an ecosystem-based approach for marine, coastal, and terrestrial environments, and its effective implementation as soft law is still questionable [43-45]. Notwithstanding the conflict of interests, the ongoing negotiations between COP resulted in the Convention on Biological Diversity (Biodiversity Convention) at that time, and its implied consideration for the protection of the marine environment with UNCLOS produced effective results in the formation of ecosystem-based ocean governance in Regional MEAs [46,47]. From the ocean's perspective, besides UNCLOS, the important developments between the progress of the IEL as mentioned earlier are the Convention on the Prevention of Marine Pollution by Dumping of Wastes and Other Matter (London Dumping Convention) and the International Convention for the Prevention of Pollution from Ships (MARPOL Convention), which deals with the ship and dumping sources of pollution $[48,49]$.

The birth of environmental and ocean diplomacy emerged when the global geopolitical system was navigating, and this provided an opportunity to the nation-states to form functional regulations for oceans. Thus, it could be argued that the fragmentation in IEL for ocean governance was manageable by the states at that time to avoid mitigation and pollution control regulations. As the global environmental and ocean governance negotiations were conducted during the development of the new world order, there were conflicting interests among the states regarding oceans and their resources [50]. Moreover, the influential states and even the developing and vulnerable states were not recognising the severity of the marine environmental issues. However, the pressure on states through international environmental organisations, academia, and UN bodies was increasing to formulate a stringent corpus for IEL. Therefore, further positive developments include the United Nations Fish Stock Agreement and Highly Migratory Fish Stocks (UNFSA) for fisheries preservation and, most recently, the draft convention for the conservation and sustainable use of Biodiversity Beyond National Jurisdiction (BBNJ Convention), which will enter into force soon for marine environmental protection at high seas [34,51].

\subsection{The Last Two Decades of Environmental Awareness for Global Ocean Governance and Establishment of UN-Oceans (An Interagency Global Mechanism of Ocean Governance)}

Over the last two decades, the UN increasingly recognised the importance of ocean governance, and after the Declaration of the World Summit on Sustainable Development (Johannesburg Declaration), it was already in the process of developing an inter-agency mechanism for ocean affairs [52,53]. However, the 2004 tsunami in the Indian Ocean triggered renewed interest in establishing coordination between various UN bodies in the ocean's ecosystems. Thus, the UN established the UN Oceans as an inter-agency mechanism on ocean affairs, covering a wide range of issues and comprises the relevant programmes, entities, and specialised agencies [16,54]. The agencies of UN, such as the International Seabed Authority (ISA), United Nations Environment Programme (UNEP), International Maritime Organization (IMO), International Oceanographic Commission (IOC), UN Development Programme (UNDP), and Intergovernmental Panel on Climate Change (IPCC) and within the UN Secretariat, the Division of Social and Economic Affairs (UN-DESA) and the Division on Ocean Affairs and Law of the Sea (UN-DOALOS), are 
a perennial part of UN-Oceans [55]. The mandate of UN-Oceans is to ensure cooperation and sharing in knowledge, information, good practices, and experiences and aims to strengthen and maintain an overview of synergies between ongoing and upcoming oceanrelated activities within the UN System [16,54].

The involvement of the diverse environmental and developmental bodies within the UN-Oceans domain depicts that the corpus of IEL is apparently expanding for positive outcomes in ocean governance. As consistent with the above-mentioned UN-Oceans mechanism (as provided in Figure 2), the UN-DOALOS, according to its mandate, monitors UNCLOS implementation, reports to the UN-Secretariat, and ensures that the UN system has the responsive capacity to assist the states [56]. UNEP is responsible for monitoring the effective implementation of the Convention on International Trade in Endangered Species of Wild Fauna and Flora (CITES), Biodiversity Convention, Aichi Bio-Diversity Targets, and Jakarta Mandate Indicators [57-60]. The IMO governs shipping under the London Dumping Convention and the MARPOL Convention [61]. Additional UN entities, ISA for marine mining and IOC for ocean scientific research, are heavily involved within the UN Oceans mechanism [55].

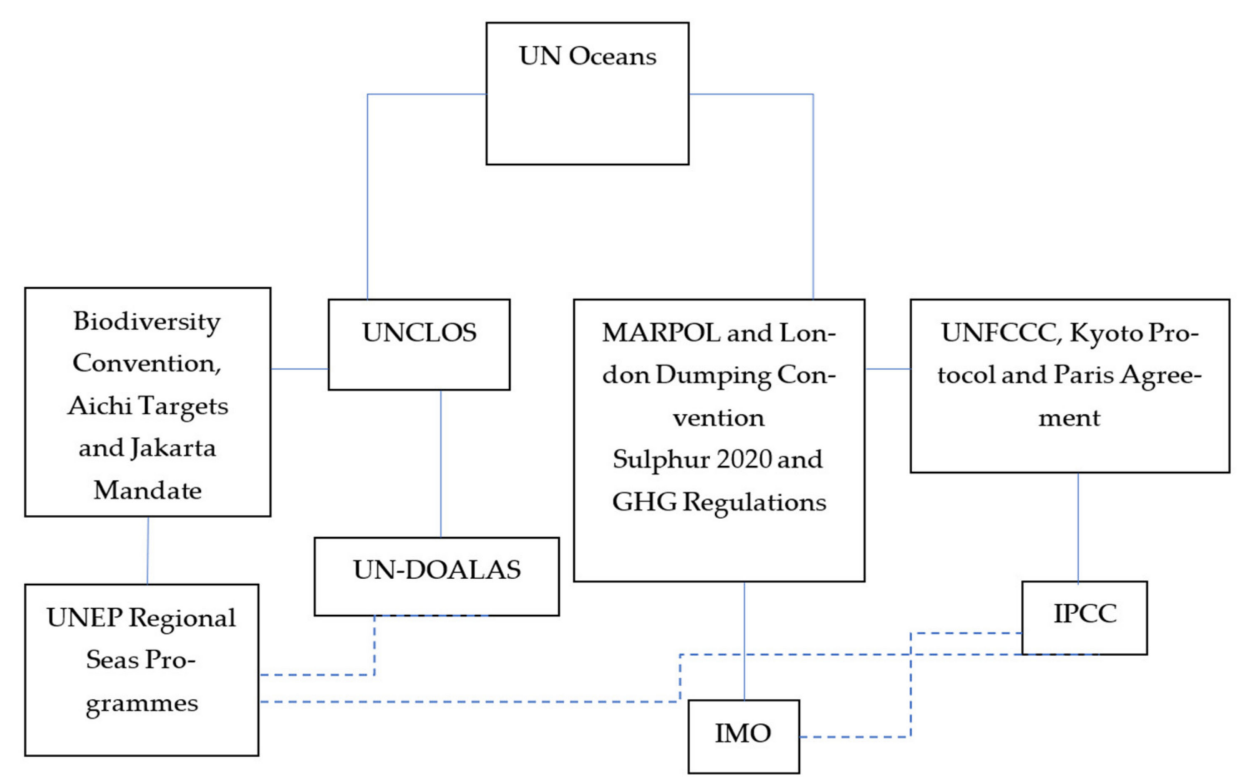

Figure 2. Mechanism of Global Ocean Governance in Marine Environmental Protection.

The most important aspect of ocean governance is information sharing to keep effective monitoring of implementation processes at the global level. The UNCLOS and related IEL places obligations on the nation-states to cooperate through international organisations for information sharing and effective monitoring and establish scientific criteria for any such collaboration [38]. Such mechanisms exist, but with insufficient information sharing and reporting systems, each UN agency focuses on its domain rather than oceans [62]. Although the Convention on Access to Information, Public Participation in Decision-Making, and Access to Justice in Environmental Matters (Aarhus Convention) has been ratified by a limited number of nation-states, it has provided effective means of information sharing systems [63]. The institutionalisation through directives and plans under Aarhus Convention brings opportunities to systematically work for interconnected marine environmental concerns, including climate change and land-based pollution [64].

Apart from problems in information sharing related to land-based pollution, the key issue observed is that the IPCC faces severe obstacles in developing information sharing mechanisms on an ecosystem basis under the United Nations Framework Convention for Climate Change (UNFCCC) Kyoto Protocol and Paris Agreement [65-68]. Although the UNFCCC and its associated regimes, along with IEL, has established measures for the systematic observation that supports scientific decision making across local and global 
levels, it has been characterised by a lack of coordination among the policy areas for climate action [69]. This has also caused ineffectiveness in implementing a specific framework in handling ocean acidification and rising sea levels because the climate-change strategies are not well aligned with ocean governance mechanisms at regional and national levels [22]. Even though various nation-states are willing to occupy leadership in global climate governance, there is a lack of capacity to address the anthropogenic climate interconnectedness, and the threats due to climate change are not fully integrated at all levels [60].

\subsection{UNDP Strategic Plan towards SDG 14 and the Future of Ocean Governance}

Despite an ambitious and ever-expanding international legal framework embodied in the various IEL treaties and declarations, the global mechanism of ocean governance is still ineffective. As ocean governance is embedded in the international geopolitical system, it requires geostrategic redressal. Thus, UNDP has recently reviewed the existing global ocean governance and proposed a Strategic Plan towards SDG 14 to redesign the mechanisms of sharing knowledge, information, management capacity, and programme development to implement a global ocean policy [70]. UNDP's ocean vision "to achieve integrated, climate-resilient, sustainable, and equitable management of water and ocean resources and universal access to safe water supply and sanitation, through improved water and ocean governance", is critical for the future of SDG 14. Furthermore, the UNDP has the mandate to convene and coordinate within UN systems and assist nation-states in improving governance through capacity development under the Rio and Johannesburg Declarations [71]. Thus, considering the significance of the UNDP plan, a task group working under the UN Oceans encouraged the development of new partnerships and the renewal of old coordination mechanisms.

Climate-resilient access to water supply and sanitation and integrated approaches to coastal management and sustainable ocean management are the priority areas identified by the UNDP. For these purposes, the UNDP proposes a framework of coordination between the IPCC, UN-Oceans, UNEP, and its Regional Seas Programmes under MEAs at the global level and cooperation among institutions governing sanitation and waste, water-ecosystems, and atmospheric environment at the national levels [70]. The proposed framework emphasises that ocean governance is obsolete if there is a weak coordination system among cross-border (regional) and national (hierarchal and horizontal integration) mechanisms under a global governance system. The ocean action is a global agenda that requires national and local action, regional coordination, and inter-regional cooperation (global collaboration) under a hierarchal framework and demands partnerships at all levels.

The UNDP framework recognises the importance of the elements of meta-governance and endorses that environmental justice through the development of strong institutions with the principles of the rule of law, accountability, and transparency is essential for effective national ocean governance. Furthermore, scientific information in decision making with the principles of equity, inclusiveness, participation, representativeness, and policy coherence, which identifies linkages, other areas for cooperation, and needs for further action with the principle of CBDG, both are of indivisible value [19,34,37]. The UNDP framework indeed acknowledges that regional partnerships for capacity building, information sharing, monitoring, and evaluation steer the holistic mechanism of ocean governance. As UNDP recognises that SDG 14 combines bottom-up and top-down approaches and aims to make networks in hierarchal and horizontal governance mechanisms [71]. The principles proposed under the UNDP's framework are reflected in a global shift of awareness due to the increasing diversity in and institutions involved in ocean action and promote joint programming, harmonisation, and cooperation at different levels.

\subsection{Regional Partnerships (MEAs) for Ocean Governance}

The contemporary ocean governance with UNCLOS and IEL, as evidenced by the establishment of many international organisations and adoption of a large number of MEAs, is the most influential system for marine environmental protection [72,73]. The UNCLOS 
and IEL are regarded as an overarching framework for regional observation and governance plans in the scope of intergovernmental arrangements [74]. Nevertheless, under the zonal approach, UNCLOS's implementation is non-institutional because of providing a separate state jurisdiction [75]. Although the UNCLOS urges to promote regional coordination concerning the implementation of rules for marine environmental protection, it remains incapable of developing the institutional mechanisms at regional levels [76]. The main challenges for institutional coordination under UNCLOS at regional levels are the same as at the global levels, including geopolitics, conflict of interests, and economic development [77]. Presumably, the states, for obvious security and developmental concerns, disregard the regional institutional arrangements. In all probability, the conflicts raise questions of the legitimacy of the regional mechanisms, leading to UNCLOS's effectiveness issues [78]. The given problems confronting regional ocean governance somehow leaves prescriptive solutions for existing arrangements and could be solved by considering the importance of regionalism in global ocean governance.

The significance of the Rio Declaration increases while considering the geopolitics mentioned above at the regional levels, as it establishes new approaches to marine environmental protection across the territorial sea [17]. Moreover, the Biodiversity Convention, London Dumping Convention, MARPOL Convention, and Jakarta Mandate, as a global consensus on the importance of marine ecosystems, insists on regional and global cooperation, including technical assistance and transfer of technology among nation-States for monitoring and environmental risk assessment and compliance with UNCLOS and IEL regarding pollution from particular sources [72]. Although the inclusive success of the given IEL is questionable, the UNEP has helped transform the institutional arrangement under regional mechanisms. This exercise of UNEP has promoted significant measures in polycentricity of ocean governance to counter marine pollution.

The UNEP's Global Programme of Action for the Protection of the Marine Environment from Land-based Activities is programmed in accordance with Rio Declaration and Jakarta Mandate [79]. This was an interesting networking aspect, as 108 governments and the European Union started working under the collaboration and designed research programmes to improve the knowledge-sharing mechanisms. The impetus was to understand the processes that form the basis for restoring and preserving marine ecosystems, including interactions with the atmosphere and the land. Such sharing of knowledge resulted in partnerships that increase access to knowledgeable advice, facilitate the work, and integrate new findings into a coherent policy. The aim was to cover practically all regions of the world, implying that learning between regional actors may lead to both the top-down and bottom-up approaches for effective ocean governance. That restructured the approach of UNEP's 13 regional seas programmes and five partner programmes that utilised networks in assessing the marine environmental conditions now focuses on the information sharing and capacity building for managing land-based sources of pollution [80].

\subsubsection{Information Sharing}

UNEP has helped in the adoption and effective implementation of UNCLOS and IEL, and most constructive programmes are binding through conventions and protocols, requiring that the information related to the state of the maritime area or activities in the area should be made available (summarised in Table 1). Information sharing based on the UNCLOS and associated IEL and specifically through Aarhus Convention is more precisely adopted by the regional programmes of Europe and Central Asia [64]. The significant development through Aarhus Convention was initially made in the Convention for the Protection of the Marine Environment of the North-East Atlantic (OSPAR Convention), which makes it mandatory that the information related to the state of the maritime area shall be available [81]. Later, many other UNEP programmes, such as the Convention on the Protection of the Marine Environment of the Baltic Sea (Helsinki Convention), Convention for the Protection of the Mediterranean Sea Against Pollution (Barcelona Convention), and Nairobi Convention through Protocol for the Protection of the Marine 
and Coastal Environment of the Western Indian Ocean from Land-Based Sources and Activities, made this requirement mandatory [23,82]. This development enabled a selfstructuring or polycentric arrangement of different institutions in a governance system to ensure the principle of transparency. The available information also helps international organisations know the state of the marine environment in any specific maritime area [28].

Table 1. The utilisation of elements of SDGs for meta-governance in Existing Regional MEAs for Ocean Governance.

\section{Programmes under Binding Conventions}

The Convention for the Protection and Development of the Marine Environment in the Wider Caribbean Region

(Cartagena Convention)

Nairobi Convention

Convention for the Protection of the Mediterranean Sea

Against Pollution (Barcelona Convention)

The Convention for Cooperation in the Protection, Management and Development of the Marine and Coastal Environment of the Atlantic Coast of the West and Central Africa Region

(Abidjan Convention)

Framework Convention for the Protection of the Marine Environment of the Caspian Sea (Tehran Convention)

Partnerships in

Environmental Management for the Seas of East Asia (PEMSEA)-Action Plan

Northwest Pacific Action Plan

Convention on the Protection of the Black Sea Against

Pollution (Bucharest Convention)

Convention for Cooperation in the Protection and

Sustainable Development of the Marine and Coastal Environment of the North-East Pacific (Antigua Convention)

\section{UNEP Administered Programmes}

\section{Instruments for the Protection of Marine Environment from Land-Based Sources}

Protocol Concerning Pollution from Land-Based Sources and Activities to the Convention for the Protection and Development of the Marine Environment of the Wider Caribbean Region

Protocol for the Protection of the

Marine and Coastal Environment of the Western Indian Ocean from

Land-Based Sources and Activities

The Protocol for the Protection of the Mediterranean Sea Against

Pollution from Land-Based Sources

Protocol concerning the Cooperation in the Protection and Development of the Marine and Coastal Environment from

Land-Based Sources and the Activities (LBSA) in the Western,

Central, and Southern Africa

Region was signed and officially adopted in 2012.

Protocol on the Protection of the Caspian Sea against Pollution

from Land based Sources and

Activities (Moscow Protocol)

\section{Nonbinding UNEP Administered Programmes}

Strategic Direction for reducing land-based pollution.

None

In process of developing adaptative measures against land-based pollution.

In progress, general coordination.

Independent Programmes Partnered with UNEP

Protocol on the Protection of the Black Sea Marine Environment

Against Pollution from

Land-Based Sources (LBS Protocol)

None

oint Assessment for Climate Change.

Integrated Climate Change Adaptation Mechanism.

Climate Change Partnership among the relevant government departments.

None

In process of developing joint monitoring and evaluation programmes [85].

Joint monitoring and evaluation [86].

General coordination programme [87].

Monitoring and evaluation with top-down and bottom-up approach [88]. 
Table 1. Cont.

\begin{tabular}{|c|c|c|c|}
\hline Regional Convention for the & Protocol Concerning the & & \\
\hline $\begin{array}{l}\text { Conservation of the Red Sea } \\
\text { and Gulf of Aden } \\
\text { Environment (Jeddah } \\
\text { Convention) }\end{array}$ & $\begin{array}{c}\text { Protection of the Marine } \\
\text { Environment from Land-Based } \\
\text { Activities in the Red Sea and Gulf } \\
\text { of Aden }\end{array}$ & $\begin{array}{c}\text { Cooperation in Scientific } \\
\text { Research. }\end{array}$ & $\begin{array}{l}\text { Monitoring with top-down } \\
\text { and bottom-up approach [90]. }\end{array}$ \\
\hline $\begin{array}{l}\text { Kuwait Regional Convention } \\
\text { for Cooperation on the } \\
\text { Protection of the Marine } \\
\text { Environment from Pollution }\end{array}$ & $\begin{array}{l}\text { Protocol for the Protection of the } \\
\text { Marine Environment against } \\
\text { Pollution from Land-Based } \\
\text { Sources (1990) }\end{array}$ & On-going negotiations & $\begin{array}{c}\text { Partnerships with } \\
\text { International Organisations } \\
\text { and Other Seas } \\
\text { Programmes-monitoring } \\
\text { and evaluation with } \\
\text { cooperation [91]. }\end{array}$ \\
\hline $\begin{array}{l}\text { Convention for the Protection } \\
\text { of the Natural Resources and } \\
\text { Environment of the South } \\
\text { Pacific Region (Noumea } \\
\text { Convention) }\end{array}$ & $\begin{array}{l}\text { Article } 7 \text { of the Convention } \\
\text { Nonbinding Independent Progra }\end{array}$ & $\begin{array}{l}\text { Climate Change Resilience } \\
\text { Programme- } \\
\text { Partnerships with the } \\
\text { Governments in the } \\
\text { Region } \\
\text { mes Partnered with UNEP }\end{array}$ & $\begin{array}{l}\text { Monitoring with top-down } \\
\text { and bottom-up approach [92]. }\end{array}$ \\
\hline $\begin{array}{c}\text { The Colombo Declaration on } \\
\text { the South Asia } \\
\text { Co-operative Environment } \\
\text { Programme }\end{array}$ & $\begin{array}{l}\text { Regional Marine Litter } \\
\text { Action Plan. }\end{array}$ & None & $\begin{array}{l}\text { In process of developing } \\
\text { mechanisms [93]. }\end{array}$ \\
\hline South-East Pacific Action Plan & $\begin{array}{c}\text { Protocol for the Protection of the } \\
\text { Southeast Pacific against } \\
\text { Pollution from Land Sources } \\
\text { UNEP Partner P }\end{array}$ & $\begin{array}{l}\text { In process of developing } \\
\text { policies on climate change. } \\
\text { grammes }\end{array}$ & $\begin{array}{l}\text { Adoption measures and } \\
\text { information sharing } \\
\text { mechanisms [94]. }\end{array}$ \\
\hline $\begin{array}{l}\text { The Convention on the } \\
\text { Conservation of Antarctic } \\
\text { Marine Living Resources }\end{array}$ & $\begin{array}{l}\text { Regional Action Plan on Marine } \\
\text { Litter in the Arctic }\end{array}$ & None & $\begin{array}{l}\text { Monitoring and evaluation } \\
\text { with top-down and } \\
\text { bottom-up approach [95]. } \\
\text { Focus marine biodiversity. } \\
\text { Monitoring and evaluation } \\
\text { with top-down and } \\
\text { bottom-up approach [96]. }\end{array}$ \\
\hline $\begin{array}{l}\text { Convention on the Protection } \\
\text { of the Marine Environment of } \\
\text { the Baltic Sea (HELCOM or } \\
\text { Helsinki Convention) } \\
\text { The Convention for the }\end{array}$ & Article 2 of the Convention & None & $\begin{array}{l}\text { Monitoring and evaluation } \\
\text { with top-down and } \\
\text { bottom-up approach [97]. }\end{array}$ \\
\hline $\begin{array}{l}\text { Protection of the Marine } \\
\text { Environment of the } \\
\text { North-East Atlantic } \\
\text { (OSPAR Convention) }\end{array}$ & Annex 1 of the Convention & $\begin{array}{l}\text { Recently considered- } \\
\text { in process. }\end{array}$ & $\begin{array}{l}\text { Monitoring and evaluation } \\
\text { with top-down and } \\
\text { bottom-up approach [98]. }\end{array}$ \\
\hline
\end{tabular}

\subsubsection{Joint Monitoring and Evaluation}

Most UNEP Programmes mutually formalised joint monitoring and evaluation mechanisms for policy enforcement in preserving the marine environment. The impetus is placed on the prevention and mitigation of land-based sources of pollution. Such approaches in regional mechanisms also help to monitor the effective implementation of IEL at the global level. In such a mechanism, the bottom-up and network approach is adopted; for example, the UNEP programme for Partnerships in Environmental Management for the Seas of East Asia (PEMSEA) conduct joint monitoring and evaluate the current state of the marine environment and share the reports with international organisations [86] (as provided in Table 1). In addition, effective monitoring programmes exist in the frameworks of OSPAR and Helsinki Conventions. Both the conventions require that state-parties must assemble lists of characteristics, pressures, and impacts related to the marine environment in the regions [97]. Moreover, the efficiency of joint-monitoring programmes is compatible with other programmes within the schemes set down in other EU legislation as an umbrella framework [99]. 


\subsubsection{Capacity Building}

Capacity building is common among all the UNEP programmes, provided that there is support for policy dialogue among governments and stakeholders and the development and promotion of good practices in the governance of land-based pollution. There are further activities conducted under the UNEP programmes, including but not limited to the public awareness, education, knowledge management, advocacy campaigns, and database platforms. Such programmes are primarily available through the Convention for the Protection and Development of the Marine Environment in the Wider Caribbean Region (Cartagena Convention), OSPAR Convention, Convention for the Protection of the Natural Resources and Environment of the South Pacific Region (Noumea Convention), and Northwest Pacific Action Plan [92,98,100] (as provided in Table 1). However, there are specific weaknesses regarding public awareness and education in other areas, specifically in the Southeast Asian and South Asian Seas, due to lack of obligation through any legal framework.

\subsubsection{Climate Change Adaptation}

Ocean acidification and rising sea levels are still with profoundly negative environmental links because the international and regional efforts at the level of climate change are more general [101]. Thus, most UNEP programmes are limited in curbing the land-based sources of pollution. A relatively more minor focus is on the integrated mechanism for climate adaptation strategy in the mitigation of ocean acidification [29]. Although the nation-state-parties under the Regional Convention for the Conservation of the Red Sea and Gulf of Aden Environment (Jeddah Convention), The Convention for Cooperation in the Protection, Management and Development of the Marine and Coastal Environment of the Atlantic Coast of the West and Central Africa Region (Abidjan Convention), Nairobi Convention, Barcelona Convention, and the Noumea Convention share the information regarding rising sea levels (coastal flood risk), they are weak regarding the capacity in implementation of mechanisms for ocean acidification mitigation [23,82,84,90,92] (as provided in Table 1). Thus, in the climate change governance arena, there shall be serious efforts to address adaptation issues in mitigation of ocean acidification and to develop measures specific to address rising sea levels. More strategic responses to climate change and the marine environment are proficiently responded under the Barcelona Convention and Noumea Convention. The nation-states under both the mentioned conventions coordinate through their respective institutions for climate change and oceans for joint mitigation strategies for ocean acidification and sea-level rise.

Climate change is often poorly understood while developing its relationship with ocean ecosystems and requires effective monitoring with learning the marine biodiversity [102]. Ocean ecosystems are even more complex in areas beyond territorial jurisdictions in which the emissions cause more destructive impacts on underwater habitats [103]. Hence, research for continuous learning, information sharing, exploration, and science is essential for better monitoring systems. The role of environmental non-governmental organisations (NGOs), scientific governmental institutions, and academia is crucial in order to provide scientific information related to oceans. At regional levels, therefore, the existing governance systems in their ongoing interactions shall consider the role of the aforesaid institutions. For an effective approach in mitigating the climate change impacts on oceans, shared goals and cooperation among and between the regional and sectoral institutions shall play a key role.

\subsubsection{SDGs for Meta-Governance in Regional Coordination for Ocean Governance}

The element of multilevel partnerships provided by SDGs for meta-governance is well utilised in UNEP programmes, and the provisions of UNCLOS and IEL support that the primary trend in global ocean governance is an increasing emphasis on regionalism [104]. Regional coordination is an indispensable part of SDG 14 and could be and is used for knowledge and information sharing and capacity building to ameliorate the degradation of 
the marine environment and effectively solve common cross-border problems [105]. However, the existing coordination requires expansion of cooperation in water- and sanitationas well as in waste-management-related activities and programmes as provided under SDG 6 and 11 [106]. Such coordination includes information sharing, monitoring and evaluation, capacity building for desalination and efficiency improvement of water ecosystems, and wastewater and waste treatment through recycling and reuse.

The discernible and recent challenge in ocean governance is disconnection among regional coordination mechanisms on marine and atmospheric environments [107]. However, the primary challenge already points to the same approach that the UNFCCC and its associated regimes can create for ocean and climate networks through harmonisation among existing governance arrangements [108]. Indeed, the SDGs for meta-governance have provided means to reorganise the existing processes and structures that shall allow international organisations, such as UNEP and IPCC, along with regional and national institutions and stakeholders, to make mutual adjustments in their ongoing work. It is further anticipated that such cooperation could provide a channel of dialogue among nation-states to restore and preserve the larger ecosystems by means of utilising regional governance.

\subsection{Mechanisms of Ocean Governance at National Levels}

A number of nation-states have in the recent decade taken concrete steps to evolve and implement an integrated vision of ocean governance under the UNCLOS and IEL [15]. The integration, however, is limited to the policy-making processes or within the policy itself and lacks coordinated implementation mechanisms [109]. Inter-governmental ocean governance is vertically oriented, seeking enhanced coordination and communication between several institutions, including local institutions. Such a realm of adaptation is especially pertinent to developed nation-states in which there is a certain level of flexibility in ocean governance [109-111]. In this context, at national levels, polycentricity exists; the institutions directly or indirectly governing oceans get involved in implementation but without or with weak coordination. SDGs for meta-governance, while realising the existing approaches, call for more scientific and participatory decision making to ensure that there is a more holistic approach in implementation mechanisms [13]. Moreover, SDGs for metagovernance provide effective means of implementation by developing and strengthening the notions of law, accountability, and transparency in existing institutions [112]. Decisive, accountable, and transparent institutions would provide open and stable implementation mechanisms for ocean governance and work for more coherent policies or plans [113].

3.6.1. SDG 16 for Ocean Governance in Development of Strong Institutions (Rule of Law, Transparency, and Accountability)

The rule of law, transparency, and accountability are principles that necessitate certain instruments for regulation, standards, and sanctions and are used repletely in the theory and practice of UNCLOS and IEL [38]. SDG 16, however, has connected the principles by requiring that the instruments that are basically for impartial implementation of law further need to establish transparent and accountable mechanisms [112,114] (as provided in Table 2). For example, the "polluter pay" principle with concepts of liability and compensation brings the economic force on the problem of environmental protection and in any such implementation, different institutions are involved at different levels [115]. In this context, ocean governance as an opaque mechanism involving various institutions that may compete in various circumstances confuses fulfilling the given duties.

Table 2. Elements of SDGs for Meta Governance and their Connections with Elements of National Mechanisms of Ocean Governance.

\begin{tabular}{lccc} 
Elements of SDGs for & Principles & Legal Framework & Exemplars \\
Meta Governance & Rule of Law $[17,38]$ & UNCLOS and Aarhus & Canada's National Programme of \\
& Transparency $[116,117]$ & Convention. & $\begin{array}{c}\text { Action for Marine Environmental } \\
\text { Protection }\end{array}$ \\
\hline
\end{tabular}


Table 2. Cont

\begin{tabular}{|c|c|c|c|}
\hline $\begin{array}{c}\text { Scientific } \\
\text { Decision Making }\end{array}$ & $\begin{array}{c}\text { Participation [97,119] } \\
\text { Inclusiveness, } \\
\text { Representativeness, } \\
\text { Responsiveness [116] }\end{array}$ & $\begin{array}{l}\text { UNCLOS, Aarhus } \\
\text { Convention, and } \\
\text { Biodiversity Convention. }\end{array}$ & $\begin{array}{c}\text { Fiji's Marine Pollution Law Series } \\
\text { under Pacific Regional Waste and } \\
\text { Pollution Management Strategy } \\
\text { 2016-2025 }\end{array}$ \\
\hline Policy Coheren & $\begin{array}{c}\text { Systemic integration [116] } \\
\text { Adaptation (Holistic and } \\
\text { ecosystem-based } \\
\text { approach) [34] } \\
\text { Precautionary approach } \\
{[120,121]}\end{array}$ & $\begin{array}{l}\text { Soft Law Declarations } \\
\text { and Biodiversity } \\
\text { Convention. }\end{array}$ & $\begin{array}{l}\text { Basic Plan on Ocean Policy of Japan } \\
\text { The Marine Environment Management } \\
\text { Act of Korea } \\
\text { Medium and Long-Term Development } \\
\text { Plans for Addressing Climate Change } \\
\text { in the Marine Field (2011-2020). }\end{array}$ \\
\hline
\end{tabular}

As provided by the UNCLOS, the nation-states have the right to decide the best and practicable means at their disposal and follow their capabilities to prevent and control marine pollution [122]. In many nation-states, this problem is responded to by environmental institutions and non-government organisations (NGOs) through available information, enabling them to hold development institutions to account for progress [123]. The recent ocean policy development in Canada is an excellent example of having strong institutions, such as the Environment Canada, which works in close collaboration with Fisheries and Oceans Canada and local institutions to protect the marine environment [124-126]. The policy is designed to re-arrange the polycentric arrangement under Canada's National Programme of Action, establishing that the institutions can conduct a more impartial implementation of the law through greater transparency and accountability because marine environmental protection is a shared responsibility. For such purposes, Environment Canada, through local institutions, applies the "polluter pay" principle and works with private stakeholders to arrange large-scale recycling of waste [127].

3.6.2. SDG 16 for Ocean Governance in Developing Processes for Scientific

Decision-Making (Responsiveness, Inclusiveness, Participation, and Representativeness)

Scientific decision making under SDG 16 is substantial in ocean governance, and it requires broad participation, inclusiveness, and representativeness of institutions and public and private organisations $[19,114]$ (as provided in Table 2). Oceans are a universal common; their governance is based on broadening and strengthening participation at the global level and demands local participation through national and regional mechanisms [128]. Within the nation-states, multiple actors bring their ideas for their own interests, which emerges in a shared vision because a participatory process to prevent, control, and mitigate adverse impacts on the marine environment helps to restore the global ecosystems [129,130]. As emphasised under UNCLOS and IEL, scientific decision making needs to consider the relevant interests of all the stakeholders in oceans with consensus, and all the participants should be aware of these processes [38].

At the national level, scientific decision making also enhances the institutions' responsive capacity in a manner bringing out competitive advantage [17]. It is a continuous, iterative, and dynamic process to allow adaptations among diverse but common ecosystems [131]. Moreover, it works through a transparent system that enables the environment for accountability and impartial implementation of the law [132]. For example, in Fiji, under the marine pollution law series programme, the ministry of environment and its constituent institutions makes decisions with participation that influence stakeholders, and it is based on a common agreement [133-135]. Through this approach, the Fijian ministry of environment responds appropriately to the marine pollution issues by involving various institutions working for diverse ecosystems. This law series in Fiji is developed under the Noumea Convention and the Cleaner Pacific Strategy (Pacific Regional Waste and Pollution Management Strategy 2016-2025) and is undoubtedly essential in managing land-based pollution by involving various stakeholders and institutions [136]. 


\subsubsection{SDG 17 for Policy Coherence for CBDG of the Oceans}

As already established, an effective ocean governance mechanism places further requirements of a coherent policy. However, the policy coherence under SDG 17 does not mean integration, and it means enhancing rationality in order to address the systemic issues [113]. Therefore, practical conduct of scientific decision making under IEL is conducted through the principle of "systemic integration", which requires harmonisation in diverse policy instruments for common goals [114,137] (as provided in Table 2). Nevertheless, harmonisation is for planning through existing policies. In this context, the holistic, ecosystem, and precautionary approaches are very important and recognised as rules of UNCLOS and IEL for marine environmental protection and are driving forces for the governance mechanisms $[24,138,139]$. Thus, integrated ocean governance in preserving the marine environment has been identified as interlinking sectoral governance (of water-ecosystems, sanitation, waste, and climate with oceans) [140].

The given approach requires a mixture of bottom-up and top-down methods of intersectoral governance to preserve the marine environment [141]. Multiple institutions and stakeholders become involved in decision making and form a network for implementation because numerous sectors are regulated independently by diverse institutions and under different rules and procedures [142]. Adaptation to respond to any such issues through holistic and ecosystem approaches is a recognised rule of IEL and is defined as the integrated governance based on knowledge of ecosystem dynamics to achieve sustainable development and ecosystem integrity [143]. Such an approach has many implications for ocean governance, and the need is to establish effective marine pollution monitoring [39]. The programme for ocean governance shall be designed to meet clear goals by providing solid information through multiple institutions. Basically, adaptation has the implicit normative aim to organise institutional framework to preserve ecosystems in multiple ocean governance problematic conceptualisations. Therefore, adaptation forms a network of institutions in ocean governance, those directly or indirectly get involved in marine environmental protection.

In order to resolve the uncertainty related to adverse environmental impacts on the marine ecosystem, a precautionary approach is necessary $[34,119,121]$. It is for effective prevention against degradation of the marine environment, and it requires where there are threats of serious and irreversible damage, scientific certainty shall be used. Moreover, if it is acknowledged that the risk is irreversible, then preventive action is applied to avoid degradation to the marine environment [144]. This approach has also been forwarded through the Jakarta Mandate by stating that the precautionary principle and ecosystembased approach are applied to the marine environment through integrated governance of local and national institutions [72]. The ambitious approach of the Jakarta Mandate reflects that CBD link restoration and conservation in every sector calls for major changes in existing programmes, and its practices in nation-states are discussed below.

\section{CBDG of Oceans, Water-Ecosystems, Sanitation, and Waste}

The local institutions conduct the governance of sanitation and waste in the nationstates (also referred to as municipal authorities or councils). Several nation-states recycle waste, dump the unrecyclable to landfill sites, and treat sanitation water so that it can flow with the freshwater falling in the oceans [145]. This employs a certain level of responsibility to local institutions and forms their relationship with national environmental or ocean governing institutions [116]. For example, in China, the local environmental protection institutions directly under the Central Government governs the waste and sanitation and responsible for organising, coordinating, overseeing, and checking the marine environment in collaboration with the central ocean governing institution (China's State Oceanic Administration) [111].

Further examples of this aspect can be found in Japan and Korea. The Basic Plan on Ocean Policy of Japan and the Marine Environment Management Act of Korea insists the local institutions must coordinate with relevant administrative institutions for marine 
environmental protection from land-based sources of pollution $[110,146]$. The governing systems have incorporated the laws for waste and sanitation in the marine environmental protection regimes with an ecosystem approach [147]. The expansion of the legal regimes is now starting to come about because responses are being demanded to question the need for conservation of the marine environment through the need for more ocean antipollution measures.

In relation to land-based pollution control, the objective of any national legislation is to ensure that pollution levels are not so high as to cause harm to the marine environment [141]. Although these objectives of marine environmental protection are not necessarily complementary, they may interfere or compete. For example, sanitation and water governance intersect at different levels, while flowing down to the sea overlaps with ocean governance [148]. This requires a sizeable integrated mechanism of governance, which must govern water ecosystems, sanitation, and oceans. However, in most nationstates, the mechanisms of water governance are limited and do not necessarily involve the local institutions.

\section{CBDG of Atmospheric-Environment and Oceans}

Generally, nation-states have already taken several measures in tackling climate change under the UNFCCC and its associated regimes [149]. Even in the developing states, there are significant policy-driven initiatives to reduce emissions and promote the environment-friendly installation of energy. For example, in Pakistan, recently there has been constituted a special institution (Alternative Energy Development Board) at the national level, which provides subsidies for the development of renewable means of energy [150]. The climate policy of Pakistan has promoted several initiatives for green energy and aims to reduce the significant amount of coal- and petroleum-based energy projects $[151,152]$. Similarly, China has devised a special policy in the field of atmospheric environmental governance that stipulates the standards, statistics, monitoring, and lowcarbon technology of emissions.

However, the UNFCCC remains incapable of inducing effective governance mechanisms at national levels to curb ocean acidification and rising sea levels. Although solving the interconnected problems does not require new legislation or institutions, it demands cooperation between the institutions governing atmospheric and marine environments [153]. There already exists a reflection of synergies in the UNFCCC with UNCLOS that prompts the requirement of national action for ocean acidification [154]. Such synergies require cooperation in monitoring sea level and ocean levels between the climate, local, and oceangoverning institutions. Given that, China has taken the lead in this task through a policy document, "Medium and Long-Term Development Plans for Addressing Climate Change in the Marine Field (2011-2020)" [107]. Further good examples are the United States of America (USA) and Australia, as both have recently developed a nested mechanism within governance structures related to climate policy and ocean acidification $[155,156]$.

The required cooperation also highlights the importance of leveraging efforts that better align international climate and ocean governance with national capacities [156]. At national levels, warning and emergency response to rising sea levels with an informationsharing mechanism shall advance global climate governance and guide ocean problems. The two pertinent national examples given in this section are China and the USA [157]. The two most significant contributors of emissions can possibly be key players if they render their efforts to mitigate climate change. Joint schemes for the promotion of renewable energy, emission trading, and regional energy interconnections may provide effective solutions [158].

\section{Meta-Governance-Bottom-Up Approach in Ocean Governance: Ocean Action Is Local}

The existing sequence of ocean governance is vertical from the international level down to the national level; this has resulted in a patchwork of regional MEAs and national policies on different levels [159]. This fragmentation in ocean governance mechanisms at 
global and regional levels is because of the crumbling processes of negotiations for IEL and has caused gaps in implementation. The idea of integrated ocean governance exists within the legal system and is subject to transfer into the domestic policies, and existing mechanisms provide only sectoral governance structures [160]. The existing practices among nation-states in ocean governance are still source based, specifically responsive rather than protective, and are a combination of polycentric national-level arrangements [161]. Most of the international and regional frameworks for ocean governance are flexible and leave the prescriptive targets and detailed descriptions to nation-states [142]. Furthermore, the institutional framework is composed of administrative mechanisms that include limited coordination and cooperation between the institutions that directly or indirectly protect the marine environment [162]. In order to avoid the fragmentation of decision-making and exclusion of stakeholders as well as in implementing an ocean governance framework, the approaches provided under SDGs for meta-governance with UNCLOS, IEL, and Regional MEAs for coordination and cooperation should be taken into consideration [105].

SDGs for meta-governance envisions the holistic and ecosystem approaches that work as direction or even driving force for the system and shall be accorded for meta-governanceocean-framework [13]. The elements provided for coordination are the nation-states' impetus in focusing on the broader notion of the marine environment as an ecosystem rather than on specific types of marine pollution. This development seems to be in response to the broad obligations imposed generally by UNCLOS and IEL, such as Rio and Johannesburg Declarations and Jakarta Mandate, and reinvigorated through SDG 14. SDG 14 is internationally codified with the IEL and is the realisation that a wide range of land-based activities, including emissions, impacts marine ecosystems' functioning [60]. The predictions of the UN are now more sharply in focus and suggest that the sectoral approaches to the marine environment were with meaningful shortcomings [163].

Furthermore, SDG 14 opened the stage for international, national, and local ocean actors to coalesce and propose ocean actions to tackle the effects of land-based pollution and emissions [164]. As it has already been recognised, vast oceans can absorb the waste, and local institutions do not have enough sites available for mounting disposal of waste. Thus, more cooperation is required at local levels from national and regional levels. Moreover, the objectives of the UNFCCC and associated regimes need institutionalisation at the local level with specific targets that can be coaligned under SDG 13 and 14 [165]. The responses shall be levelled here through nation-states and in becoming conservation oriented and regionally cooperative. This shall also highlight the importance of leveraging sustainability efforts through the assistance of technical means to reduce and recycle waste that better align global governance capacities with local capacities as provided under SDG 6 and 11 [21]. The provided considerations support the development of compatible programmes while fostering robust partnerships among local institutions.

Based on the aforesaid, ocean governance under SDG 14 needs national and local governmental interdisciplinary adaptation, wherefore IEL emphasises the need for coherence of national ocean policy to develop coordinating programs for preserving the marine environment [166]. Each nation-state needs to find out or further develop plans and programmes of effective implementation for SDG 14 while combining the development of strategies at local levels with the UNCLOS and IEL [17]. Within each nation-state, local institutions span across jurisdictions that can facilitate coordination between national and regional ocean-related institutions and promote a collaborative decision-making system linking all ocean stakeholders, including international institutions [162]. There shall be specific targets at local levels given by national, regional, and international institutions on monitoring of progress and against these targets by the comprehensive indicator set could be achieved [140]. An additional requirement is an appropriate reflection of the interdependence between the atmospheric and blue economies based on productive marine ecosystems [22].

In the achievement of SDG 14 through regional implementation, the explicit endorsement provided by the targets 17.16 for regional partnerships and 16.a for the international 
capacity building provided under targets and indicator set of SDGs is critical for regional ocean governance $[9,25,30,128]$. The given targets provide means to share information and technology, conduct joint monitoring and evaluation, and strengthen the relevant national institutions through regional cooperation. These targets to minimise and address the impacts of ocean acidification, rising sea levels, and reduce land-based pollution through enhanced scientific cooperation at regional levels require (as provided in Figure 3):

1. (SDG 13.1) Promotion of mechanisms for raising capacity and strengthening resilience and adaptation for effective climate change-related governance in all countries [11,165,167];

2. (SDG 11.a) Positive environmental links by strengthening regional governance $[9,166]$; and

3. (SDG 6.3, 6.5, and 6.a) Implementation of integrated water resources governance through transboundary cooperation and through expanding international cooperation and capacity-building support in water- and sanitation-related governance, including water harvesting, desalination, water efficiency, wastewater treatment, recycling, and reuse technologies $[9,168]$.

At the national level, a much broader, ecosystem-based approach is required for SDG 14 provided under the targets 16.3 for promoting the rule of law to ensure equal access to environmental justice, 16.6 for developing effective (accountable and transparent) institutions, and 16.7 for scientific (responsive, inclusive, participatory, and representative) decision making $[9,13,38,166]$. The set targets for SDG 14 are also provided by UNCLOS and IEL and are applicable to address adaptive governance of atmospheric, terrestrial, and ocean ecosystems by the provision of the following means (as provided in Figure 3):

4. (SDG 13.2) Integration of climate change policies into national planning and resilient and adaptive capacity to tackle climate-related hazards [107];

5. (SDG 11.6) Reduction of the adverse per capita environmental impact of cities, including by paying special attention to the governance of atmospheric environment and municipal and other waste [145]; and

6. (SDG 6.3, 6.5, 6.a, and 6.b) Participation of local communities in improving governance of water and sanitation and improvement in water quality by reducing pollution, eliminating dumping and minimising release of hazardous chemicals and materials, halving the proportion of untreated wastewater, and substantially increasing recycling and safe reuse globally $[9,139]$.

The areas of policy coherence under SDG 17.14 with the principles of systemic integration, adaptation, and precaution shall establish (as provided in Figure 3):

7. Regional monitoring system through cooperation in information sharing and evaluation of ocean health by an adequate set of indicators for measuring ocean health at the local level to comprehensively assess the progress [169];

8. Intergovernmental review systems through a continuous system to consider the progress of implementation of any marine environmental programme through local institutions and ocean-related institutions at the national level, compared with the results of the assessments, to provide directions in responding to new challenges and ensure that existing initiatives are coherent and performing effectively [125,170];

9. Mechanisms to organise and expedite the exchange of capacity building techniques, information, experience, and expertise to help local institutions through regional cooperation in mitigation of land-based sources of pollution and national institutions for reducing emissions [128,165];

10. Scientific decision making by involving the institutions directly or indirectly involved in ocean governance [171];

11. Plan of action at national level considering UNCLOS, IEL, and Regional MEAs as well as the documents defining objectives, such as indicator set of sustainable development goals, with policy coherence in the protection of the marine environment with diverse ecosystems as provided above [71]; and 
12. Constitution of mechanisms to diagnose problems through coordination among national and local institutions in identifying appropriate solutions for mitigation of marine pollution and providing appropriate solutions of the problems through institutional coordination for providing minimum safe standards supplementing the targets of emissions to maintain ocean health and conducting a scientific assessment of the marine environment on periodical basis at national level by involving all the relevant institutions $[171,172]$.

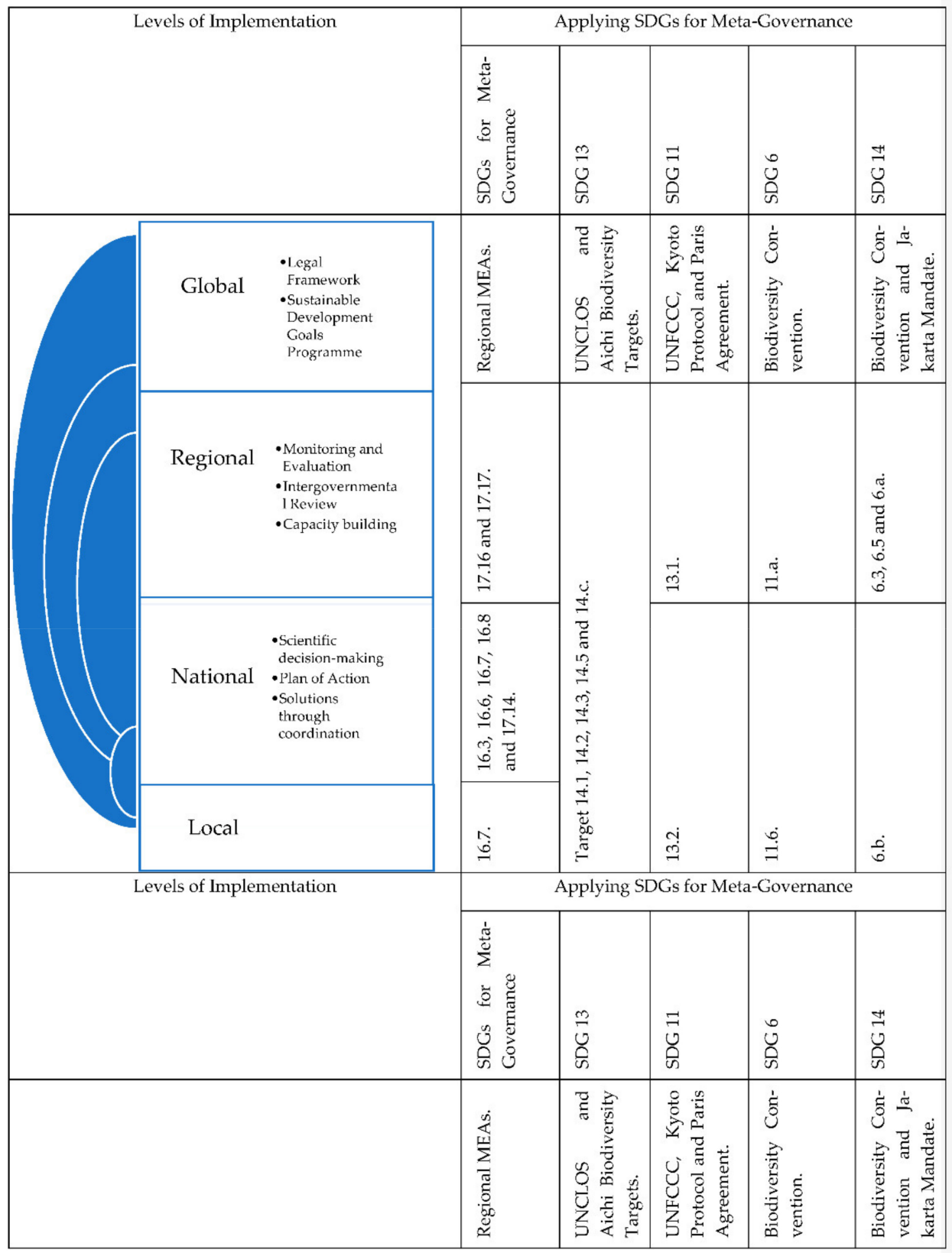

Figure 3. Meta-governance of the oceans under the indicator set of SDGs.

\section{Conclusions}

As evident from the above analysis and discussion, innumerable literature has focused on ocean governance with the approach of "oceans as common community's interest" with the principles of erga omnes and ius cogens. Such literature suggests that the treatment of SDG 14 through ocean governance as a policy issue is virtually about disconnected silos, and due to absence of plans and programmes, creates a clear need for re-arrangement. 
All the existing processes and structures allow international and regional organisations, nation-states, and stakeholders to make mutual adjustments in their ongoing work. The literature also suggests that policy coherence, strong institutions, scientific decision making, and regional partnerships shall reflect the ecosystem-based approach in ocean governance and address with great care the substitution between atmospheric, terrestrial, and marine environments.

Hence, it could be assumed that the structure of ocean governance in future shall be based on the idea of "the ocean as a global common pool of resources and a space of shared responsibilities", which essentially seeks stable and equitable geopolitical power. The perception of a need for change that motivated SDG 14, consisting of environmental targets, links it with all SDG 6,11, and 13, comprehensively redressed through a meta-governance framework. Plans and programmes by using innovative policy instruments and extending efforts to mainstream impacting governance mechanisms at national levels are essential for marine environmental protection. Identification of new pathways for ocean governance requires examining and developing specific legal rules and flexible plans, considering that international cooperation is essential for the advancement of the institutionalised mechanisms. A complex web of binding and nonbinding strategic frameworks of ocean governance exists at global and regional levels. Mainly, the UN specialised agencies wholly or partially involved in ocean affairs under the UN-Oceans is a good example of network governance. Thus, regional cooperation, particularly on the commons, looks like a possible alternative that could work as a provisional arrangement for ocean governance in the near future.

Author Contributions: Conceptualization, M.J.B. and K.Z.; methodology, K.Z.; formal analysis, M.J.B.; investigation, K.Z.; resources, M.J.B.; data curation, K.Z.; writing—original draft preparation, K.Z.; writing - review and editing, M.J.B. Both authors have read and agreed to the published version of the manuscript.

Funding: The funding for writing this paper is provided by China Scholarship Council and Dalian Maritime University.

Acknowledgments: The resources used in this paper are provided by the Law School of Dalian Maritime University.

Conflicts of Interest: The authors declare no conflict of interest.

\section{References}

1. Robinson, N.A. Environmental Law: Is an Obligation Erga Omnes Emerging; Paper Presented by Permanent Mission of Colombia to the United Nations during Panel Discussion at the United Nations; IUCN: Gland, Switzerland, 2018. Available online: https://www.iucn.org/sites/dev/files/content/documents/2018/environmental_law_is_an_obligation_erga_omnes_ emerging_interamcthradvisoryopinionjune2018.pdf (accessed on 3 September 2021).

2. Stevoli, M. Comunità Internazionale e Obblighi “Erga Omnes". Chin. J. Int. Law 2013, 12, 846-847. [CrossRef]

3. United Nations. Convention on Law of the Sea. 1982. Available online: https://treaties.un.org/doc/Publication/UNTS/ Volume\%201833/volume-1833-A-31363-English.pdf (accessed on 3 September 2021).

4. Shigeta, Y. Obligations to Protect the Environment in the ICJ's Practice: To What Extent Erga Omnes. Jpn. Y.B. Int. L. 2012, 55, 176.

5. Freestone, D. Principles Applicable to Modern Oceans Governance. Int. J. Mar. Coast. Law 2008, 23, 385-391. [CrossRef]

6. Young, O.R. Governing the Arctic Ocean. Mar. Policy 2016, 72, 271-277. [CrossRef]

7. United Nations. The Rio Declaration on Environment and Development. In Proceedings of the Conference Declaration on Environment and Development, Rio De Janeiro, Brazil, 3-14 June 1992.

8. Miles, G.; Fuavao, V.; Smith, A. Implementing Agenda 21: Oceans, Coasts and the Barbados Outcomes in the Pacific Region. Ocean Coast. Manag. 1995, 29, 125-138. [CrossRef]

9. United Nations Department of Economic and Social Affairs. Final List of Proposed Sustainable Development Goal Indicators; Report of the Inter-Agency and Expert Group on Sustainable Development Goal Indicators; UN Statistical Commission: New York, NY, USA, 2016. Available online: https://sustainabledevelopment.un.org/content/documents/11803Official-List-of-Proposed-SDGIndicators.pdf (accessed on 3 September 2021).

10. Visbeck, M.; Kronfeld-Goharani, U.; Neumann, B.; Rickels, W.; Schmidt, J.; van Doorn, E.; Matz-Lück, N.; Proelss, A. A Sustainable Development Goal for the Ocean and Coasts: Global Ocean Challenges Benefit from Regional Initiatives Supporting Globally Coordinated Solutions. Mar. Policy 2014, 49, 87-89. [CrossRef] 
11. Cormier, R.; Elliott, M. Smart Marine Goals, Targets and Management-Is SDG 14 Operational or Aspirational, is 'Life Below Water' Sinking or Swimming? Mar. Pollut. Bull. 2017, 123, 28-33. [CrossRef] [PubMed]

12. Islam, M.M.; Shamsuddoha, M. Coastal and Marine Conservation Strategy for Bangladesh in the Context of Achieving Blue Growth and Sustainable Development Goals (SDGs). Environ. Sci. Policy 2018, 87, 45-54. [CrossRef]

13. Meuleman, L.; Niestroy, I. Common but Differentiated Governance: A Metagovernance Approach to Make the SDGs Work. Sustainability 2015, 7, 12295-12321. [CrossRef]

14. Greenhill, L.; Kenter, J.O.; Dannevig, H. Adaptation to Climate Change-Related Ocean Acidification: An Adaptive Governance Approach. Ocean Coast. Manag. 2020, 191, 105176. [CrossRef]

15. Chang, Y.-C. A Note on a Comparison of the Ocean Governance System Between Mainland China and Taiwan. Ocean Dev. Int. Law 2012, 43, 311-329. [CrossRef]

16. Ryabinin, V.; Barbière, J.; Haugan, P.; Kullenberg, G.; Smith, N.; McLean, C.; Troisi, A.; Fischer, A.; Aricò, S.; Aarup, T.; et al. The UN Decade of Ocean Science for Sustainable Development. Front. Mar. Sci. 2019, 6, 1-10. [CrossRef]

17. Chang, Y.-C. Good Ocean Governance. Ocean Yearb. Online 2009, 23, 89-118. [CrossRef]

18. Campbell, L.M.; Gray, N.J.; Fairbanks, L.; Silver, J.J.; Gruby, R.L.; Dubik, B.A.; Basurto, X. Global Oceans Governance: New and Emerging Issues. Available online: https:/ / www.annualreviews.org/doi/abs/10.1146/annurev-environ-102014-021121 (accessed on 25 August 2021).

19. Meuleman, L. Guiding Principles. In Metagovernance for Sustainability: A Framework for Implementing the Sustainable Development Goals; Routledge: London, UK, 2019.

20. Meuleman, L. (Ed.) Theoretical framework. In Public Management and the Metagovernance of Hierarchies, Networks and Markets: The Feasibility of Designing and Managing Governance Style Combinations; Contributions to Management Science; Physica HD: Heidelberg, Germany, 2008; pp. 9-86, ISBN 978-3-7908-2054-6.

21. Ntona, M.; Morgera, E. Connecting SDG 14 with the Other Sustainable Development Goals through Marine Spatial Planning. Mar. Policy 2018, 93, 214-222. [CrossRef]

22. Baird, R.; Simons, M.; Stephens, T. Ocean Acidification: A Litmus Test for International Law. Carbon Clim. Law Rev. 2009, 3, 459-471. [CrossRef]

23. Kimball, L.A. An International Regime for Managing Land-Based Activities That Degrade Marine and Coastal Environments. Ocean Coast. Manag. 1995, 29, 187-206. [CrossRef]

24. Visbeck, M.; Kronfeld-Goharani, U.; Neumann, B.; Rickels, W.; Schmidt, J.; van Doorn, E.; Matz-Lück, N.; Ott, K.; Quaas, M.F. Securing Blue Wealth: The Need for a Special Sustainable Development Goal for the Ocean and Coasts. Mar. Policy 2014, 48, 184-191. [CrossRef]

25. Mahon, R.; Fanning, L. Regional Ocean Governance: Integrating and Coordinating Mechanisms for Polycentric Systems. Mar. Policy 2019, 107, 103589. [CrossRef]

26. Van Leeuwen, J. The Regionalization of Maritime Governance: Towards a Polycentric Governance System for Sustainable Shipping in the European Union. Ocean Coast. Manag. 2015, 117, 23-31. [CrossRef]

27. Acton, L.; Gruby, R.L.; Nakachi, A. Does Polycentricity Fit? Linking Social Fit with Polycentric Governance in a Large-Scale Marine Protected Area. J. Environ. Manag. 2021, 290, 112613. [CrossRef]

28. Tanaka, Y. Reflections on Reporting Systems in Treaties Concerning the Protection of the Marine Environment. Ocean Dev. Int. L. 2009, 40, 146-170. [CrossRef]

29. Rochette, J.; Billé, R.; Molenaar, E.J.; Drankier, P.; Chabason, L. Regional Oceans Governance Mechanisms: A Review. Mar. Policy 2015, 60, 9-19. [CrossRef]

30. Degger, N.; Hudson, A.; Mamaev, V.; Hamid, M.; Trumbic, I. Navigating the Complexity of Regional Ocean Governance through the Large Marine Ecosystems Approach. Front. Mar. Sci. 2021, 8, 645668. [CrossRef]

31. Fanning, L.; Mahon, R.; Compton, S.; Corbin, C.; Debels, P.; Haughton, M.; Heileman, S.; Leotaud, N.; McConney, P.; Moreno, M.P.; et al. Challenges to Implementing Regional Ocean Governance in the Wider Caribbean Region. Front. Mar. Sci. 2021, 8, 286. [CrossRef]

32. Dauvergne, P. Why Is the Global Governance of Plastic Failing the Oceans? Glob. Environ. Change 2018, 51, 22-31. [CrossRef]

33. Pyc, D. Global Ocean Governance. Int. J. Mar. Navig. Saf. Sea Transp. 2018, 10, 159-163. [CrossRef]

34. Houghton, K. Identifying New Pathways for Ocean Governance: The Role of Legal Principles in Areas beyond National Jurisdiction. Mar. Policy 2014, 49, 118-126. [CrossRef]

35. Bolis, I.; Morioka, S.N.; Sznelwar, L.I. When Sustainable Development Risks Losing Its Meaning. Delimiting the Concept with a Comprehensive Literature Review and a Conceptual Model. J. Clean. Prod. 2014, 83, 7-20. [CrossRef]

36. Paavola, J. Institutions and Environmental Governance: A Reconceptualization. Ecol. Econ. 2007, 63, 93-103. [CrossRef]

37. Biermann, F.; Abbott, K.; Andresen, S.; Bäckstrand, K.; Bernstein, S.; Betsill, M.M.; Bulkeley, H.; Cashore, B.; Clapp, J.; Folke, C.; et al. Transforming Governance and Institutions for Global Sustainability: Key Insights from the Earth System Governance Project. Curr. Opin. Environ. Sustain. 2012, 4, 51-60. [CrossRef]

38. Chang, Y.-C. International Legal Obligations in Relation to Good Ocean Governance. Chin. J. Int. Law 2010, 9, 589-605. [CrossRef]

39. Belsky, M.H. Management of Large Marine Ecosystems: Developing a New Rule of Customary International Law Law of the Sea Conference. San Diego L. Rev. 1985, 22, 733-764. 
40. Cicin-Sain, B.; Knecht, R.W. Implications of the Earth Summit for Ocean and Coastal Governance. Ocean Dev. Int. Law 1993, 24, 323-353. [CrossRef]

41. Haward, M. Plastic Pollution of the World's Seas and Oceans as a Contemporary Challenge in Ocean Governance. Nat. Commun. 2018, 9, 667. [CrossRef] [PubMed]

42. Minas, S.; Diamond, H.J. Introduction: The Law of the Sea and the Challenges of Transnational Governance. In Stress Testing the Law of the Sea; Brill: Leiden, The Netherlands, 2018; pp. 1-7. [CrossRef]

43. Skjærseth, J.B.; Stokke, O.S.; Wettestad, J. Soft Law, Hard Law, and Effective Implementation of International Environmental Norms. Glob. Environ. Politics 2006, 6, 104-120. [CrossRef]

44. Pallemaerts, M. International Environmental Law from Stockholm to Rio: Back to the Future? Rev. Eur. Community Int. Environ. Law 1992, 1, 254-266. [CrossRef]

45. United Nations. Declaration of the United Nations Conference on the Human Environment; United Nations: Stockholm, Sweden, 1972.

46. Enright, S.R.; Boteler, B. The Ecosystem Approach in International Marine Environmental Law and Governance. In Ecosystem-Based Management, Ecosystem Services and Aquatic Biodiversity: Theory, Tools and Applications; O'Higgins, T.G., Lago, M., DeWitt, T.H., Eds.; Springer International Publishing: Cham, Switzerland, 2020; pp. 333-352, ISBN 978-3-030-45843-0.

47. United Nations. Convention on Biological Diversity. 1992. Available online: https://treaties.un.org/doc/Publication/UNTS/ Volume\%201760/v1760.pdf (accessed on 3 September 2021).

48. United Nations. Convention for Prevention of Marine Pollution by Dumping of Wastes and Other Matter. 1972. Available online: https:/ / treaties.un.org/doc/Publication/UNTS/Volume\%201046/v1046.pdf (accessed on 3 September 2021).

49. United Nations. International Convention for the Prevention of Pollution from Ship (MARPOL 73/78). 1973. Available online: https:/ / treaties.un.org/doc/Publication/UNTS/Volume\%201340/volume-1340-A-22484-English.pdf (accessed on 3 September 2021).

50. Prip, C. Arctic Ocean Governance in Light of an of an International Legally Binding Instrument on the Conservation and Sustainable Use of Marine Biodiversity of Areas beyond National Jurisdiction. Mar. Policy 2019, 103768. [CrossRef]

51. United Nations. Agreement for the Implementation of the Provisions of the United Nations Convention on the Law of the Sea of 10 December 1982 Relating to the Conservation and Management of Straddling Fish Stocks and Highly Migratory Fish Stocks. 1995. Available online: https://treaties.un.org/doc/Publication/UNTS/Volume\%202167/v2167.pdf (accessed on 3 September 2021).

52. Hens, L.; Nath, B. The Johannesburg Conference. In The World Summit on Sustainable Development: The Johannesburg Conference; Hens, L., Nath, B., Eds.; Springer: Dordrecht, The Netherlands, 2005; pp. 1-33, ISBN 978-1-4020-3653-8.

53. United Nations Educational, Scientific and Cultural Organization. Summary Report: Seventeenth Meeting of UN-Oceans; Paris, France, 2018; p. 23. Available online: https:/ / unsceb.org/sites/default/files/2020-12/UN-Oceans-2018-Report-17.pdf (accessed on 3 September 2021).

54. Schubert, S.; Gupta, J. Comparing Global Coordination Mechanisms on Energy, Environment, and Water. Ecol. Soc. 2013, 18, 22. [CrossRef]

55. Watson-Wright, W.; Valdés, J.L. Fragmented Governance of Our One Global Ocean. In The Future of Ocean Governance and Capacity Development; Werle, D., Boudreau, P.R., Brooks, M.R., Butler, M.J.A., Charles, A., The International Ocean Institute-Canada, Eds.; Essays in Honor of Elisabeth Mann Borgese (1918-2002); Brill Nijhoff: Leiden, The Netherlands, 2018; p. 16.

56. Goettsche-Wanli, G. The Role of the United Nations, including its Secretariat in Global Ocean Governance. In The IMLI Treatise on Global Ocean Governance: Volume I: UN and Global Ocean Governance; Attard, D., Ong, D., Kritsiotis, D., Eds.; Oxford University Press: Oxford, NY, USA, 2018; p. 14, ISBN 978-0-19-882415-2.

57. United Nations. Regional Seas and the Convention on Biological Diversity; United Nations Environment Programme: Beijing, China, 2006; pp. 1-3.

58. Bax, N.J.; Cleary, J.; Donnelly, B.; Dunn, D.C.; Dunstan, P.K.; Fuller, M.; Halpin, P.N. Results of efforts by the Convention on Biological Diversity to describe ecologically or biologically significant marine areas. Conserv. Biol. 2016, 30, 571-581. [CrossRef]

59. Jonas, H.; Lucas, S. Legal Aspects of Aichi Biodiversity Target 11; Working Paper; International Development Law Organization: Geneva, Switzerland, 2011; p. 23.

60. Rees, S.E.; Foster, N.L.; Langmead, O.; Pittman, S.; Johnson, D.E. Defining the Qualitative Elements of Aichi Biodiversity Target 11 with Regard to the Marine and Coastal Environment in Order to Strengthen Global Efforts for Marine Biodiversity Conservation Outlined in the United Nations Sustainable Development Goal 14. Mar. Policy 2018, 93, 241-250. [CrossRef]

61. Grech, A.; Bos, M.; Brodie, J.; Coles, R.; Dale, A.; Gilbert, R.; Hamann, M.; Marsh, H.; Neil, K.; Pressey, R.L.; et al. Guiding Principles for the Improved Governance of Port and Shipping Impacts in the Great Barrier Reef. Mar. Pollut. Bull. 2013, 75, 8-20. [CrossRef]

62. Spalding, A.K.; de Ycaza, R. Navigating Shifting Regimes of Ocean Governance: From UNCLOS to Sustainable Development Goal 14. Environ. Soc. 2020, 11, 5-26. [CrossRef]

63. United Nations. Convention on Access to Information, Public Participation in Decision-Making and Access to Justice in Environmental Matters. 1998. Available online: https://treaties.un.org/doc/Treaties/1998/06/19980625\%2008-35\%20AM/3777 0-En.pdf (accessed on 3 September 2021).

64. Mason, M. Information Disclosure and Environmental Rights: The Aarhus Convention. Glob. Environ. Politics 2010, 10, 10-31. [CrossRef] 
65. United Nations. Framework Convention on Climate Change. 1992. Available online: https://treaties.un.org/doc/Publication/ UNTS/Volume\%201771/v1771.pdf (accessed on 3 September 2021).

66. Kyoto Protocol to the United Nations Framework Convention on Climate Change. 1997. Available online: https://treaties.un. org/doc/Publication/UNTS/Volume\%202303/v2303.pdf (accessed on 3 September 2021).

67. Paris Agreement to the United Nations Framework Convention on Climate Change. 2016. Available online: https://treaties.un. org/doc/Publication/UNTS/No\%20Volume/54113/Part/I-54113-0800000280458f37.pdf (accessed on 3 September 2021).

68. Amundsen, H.; Berglund, F.; Westskog, H. Overcoming Barriers to Climate Change Adaptation-A Question of Multilevel Governance? Env. Plann C Gov Policy 2010, 28, 276-289. [CrossRef]

69. Aktypis, S.; Decaux, E.; Leroy, B. Systemic integration between climate change and human rights at the United Nations? In Climate Change and Human Rights: An International and Comparative Law Perspective; Routledge: Oxfordshire, UK, 2016.

70. Water and Ocean Governance. Available online: https://www.undp.org/content/undp/en/home/2030-agenda-for-sustainabledevelopment/planet/environment-and-natural-capital/water-and-ocean-governance.html (accessed on 5 August 2019).

71. Kirk, E.A. UNDP and Ocean Governance. In The IMLI Treatise on Global Ocean Governance: Volume I: UN and Global Ocean Governance; Attard, D., Ong, D., Kritsiotis, D., Eds.; Oxford University Press: Oxford, NY, USA, 2018; p. 57, ISBN 978-0-19-882415-2.

72. Grip, K. International Marine Environmental Governance: A Review. Ambio 2017, 46, 413-427. [CrossRef] [PubMed]

73. Fanning, L.; Mahon, R. Governance of the Global Ocean Commons: Hopelessly Fragmented or Fixable? Coast. Manag. 2020, 48, 527-533. [CrossRef]

74. Gardiner, N.B. Marine Protected Areas in the Southern Ocean: Is the Antarctic Treaty System Ready to Co-Exist with a New United Nations Instrument for Areas beyond National Jurisdiction? Mar. Policy 2020, 122, 104212. [CrossRef]

75. Maes, F. The International Legal Framework for Marine Spatial Planning. Mar. Policy 2008, 32, 797-810. [CrossRef]

76. The 1982 Law of the Sea Convention at 30: Successes, Challenges and New Agendas; Brill Nijhoff: Leiden, The Netherlands, 2013; ISBN 978-90-04-24504-4.

77. Suárez de Vivero, J.L.; Rodríguez Mateos, J.C. Ocean Governance in a Competitive World. The BRIC Countries as Emerging Maritime Powers-Building New Geopolitical Scenarios. Mar. Policy 2010, 34, 967-978. [CrossRef]

78. Germond, B.; Germond-Duret, C. Ocean Governance and Maritime Security in a Placeful Environment: The Case of the European Union. Mar. Policy 2016, 66, 124-131. [CrossRef]

79. VanderZwaag, D.L.; Wells, P.G.; Karau, J. Environment: The Global Programme of Action for the Protection of the Marine Environment from Land-Based Activities: A Myriad of Sounds, Will the World Listen? Ocean Yearb. Online 1998, 13, 183-210. [CrossRef]

80. Meier-Wehren, B. The Global Programme of Action for the Protection of the Marine Environment from Land-Based Activities. N. Z. J. Envtl. L. 2013, 17, 1.

81. Convention for the Protection of Marine Environment of the North-East Atlantic. 1992. Available online: https://treaties.un.org/ doc/Publication/UNTS/Volume\%202354/v2354.pdf (accessed on 3 September 2021).

82. Raftopoulos, E. The Barcelona Convention System for the Protection of the Mediterranean Sea Against Pollution: An International Trust at Work. Int. J. Estuar. Coast. Law 1992, 7, 27-41. [CrossRef]

83. Fanning, L.; Mahon, R.; McConney, P. Applying the Large Marine Ecosystem (LME) Governance Framework in the Wider Caribbean Region. Mar. Policy 2013, 42, 99-110. [CrossRef]

84. Barnes-Dabban, H.; Karlsson-Vinkhuyzen, S. The Influence of the Regional Coordinating Unit of the Abidjan Convention: Implementing Multilateral Environmental Agreements to Prevent Shipping Pollution in West and Central Africa. Int. Environ. Agreem. Politics Law Econ. 2018, 18, 469-489. [CrossRef]

85. Seyrafi, S. Submarine Oil and Gas Pipelines under the Aktau Convention and the EIA Protocol to the Tehran Convention. Cent. Eurasia Stud. 2020, 13, 117-142. [CrossRef]

86. Chua, T.-E. Coastal and Ocean Governance in the Seas of East Asia: PEMSEA's Experience. Coast. Manag. 2013, 41, 99-119. [CrossRef]

87. United Nations. Environment Programme Guidelines for Monitoring Marine Litter on the Seabed in the Northwest Pacific Region. 2010. Available online: https:/ /wedocs.unep.org/bitstream/handle/20.500.11822/26159/GuidelinesmonitoringML. pdf? sequence $=1 \&$ isAllowed $=y$ (accessed on 3 September 2021).

88. Frantzi, S.; Brouwer, R.; Watkins, E.; van Beukering, P.; Cunha, M.C.; Dijkstra, H.; Duijndam, S.; Jaziri, H.; Okoli, I.C.; Pantzar, M.; et al. Adoption and Diffusion of Marine Litter Clean-up Technologies across European Seas: Legal, Institutional and Financial Drivers and Barriers. Mar. Pollut. Bull. 2021, 170, 112611. [CrossRef]

89. United Nations Environment Programme Secretariat of the Pacific Environment Programme-The SPREP Convention. UNEPUN Environment Programme. 2017. Available online: https:/ /www.unep.org/explore-topics/oceans-seas/what-we-do/workingregional-seas/regional-seas-programmes / pacific (accessed on 3 September 2021).

90. Kleinhaus, K.; Al-Sawalmih, A.; Barshis, D.J.; Genin, A.; Grace, L.N.; Hoegh-Guldberg, O.; Loya, Y.; Meibom, A.; Osman, E.O.; Ruch, J.-D.; et al. Science, Diplomacy, and the Red Sea's Unique Coral Reef: It's Time for Action. Front. Mar. Sci. $2020,7,90$. [CrossRef]

91. Nadim, F.; Bagtzoglou, A.C.; Iranmahboob, J. Coastal Management in the Persian Gulf Region within the Framework of the ROPME Programme of Action. Ocean Coast. Manag. 2008, 51, 556-565. [CrossRef] 
92. Tilot, V.; Willaert, K.; Guilloux, B.; Chen, W.; Mulalap, C.Y.; Gaulme, F.; Bambridge, T.; Peters, K.; Dahl, A. Traditional Dimensions of Seabed Resource Management in the Context of Deep Sea Mining in the Pacific: Learning From the SocioEcological Interconnectivity Between Island Communities and the Ocean Realm. Front. Mar. Sci. 2021, 8, 637938. [CrossRef]

93. Pernetta, J.; Wells, S. Marine Protected Area Needs in the South Asian Seas Region: Maldives; IUCN: Gland, Switzerland, 1993; Volume 3.

94. Jara, M.R.; Guarda, T. Insertion in the Asia-Pacific the Economic Cooperation Forum: Challenges for the Countries of the South-East Pacific from the Security Perspective. Rev. Ibérica De Sist. E Tecnol. De Inf. 2018, 15, 100-105.

95. Montgomery-Andersen, R.; Douglas, V.; Borup, I. Literature Review: The 'Logics' of Birth Settings in Arctic Greenland. Midwifery 2013, 29, e79-e88. [CrossRef] [PubMed]

96. Howard, M. The Convention on the Conservation of Antarctic Marine Living Resources: A Five-Year Review. Int. Comp. Law Q. 1989, 38, 104. [CrossRef]

97. Juda, L. The European Union and the Marine Strategy Framework Directive: Continuing the Development of European Ocean Use Management. Ocean Dev. Int. Law 2010, 41, 34-54. [CrossRef]

98. Huang, Y.; Vuong, P.T. Marine Protected Areas in ABNJ versus the Principle of High Seas Freedom: Possible Pathway from the OSPAR Experience. In Sustainable Development and the Law of the Sea; Zou, K., Ed.; Maritime Cooperation in East Asia; Brill Nijhoff: Leiden, The Netherlands, 2017; Volume 2, pp. 175-193.

99. Long, R. The Marine Strategy Framework Directive: A New European Approach to the Regulation of the Marine Environment, Marine Natural Resources and Marine Ecological Services. J. Energy Nat. Resour. L. 2011, 29, 1-44. [CrossRef]

100. Mahon, R. Exploring Scale in Ocean and Coastal Governance in the Wider Caribbean. Gulf Caribb. Res. 2020, 31, xxix-xlviii. [CrossRef]

101. Galdies, C.; Bellerby, R.; Canu, D.; Chen, W.; Garcia-Luque, E.; Gašparović, B.; Godrijan, J.; Lawlor, P.J.; Maes, F.; Malej, A.; et al. European Policies and Legislation Targeting Ocean Acidification in European Waters-Current State. Mar. Policy 2020, 118, 103947. [CrossRef]

102. Fox, A.D.; Henry, L.-A.; Corne, D.W.; Roberts, J.M. Sensitivity of Marine Protected Area Network Connectivity to Atmospheric Variability. R. Soc. Open Sci. 2016, 3, 160494. [CrossRef]

103. Ortuño Crespo, G.; Dunn, D.C. A Review of the Impacts of Fisheries on Open-Ocean Ecosystems. ICES J. Mar. Sci. 2017, 74, 2283-2297. [CrossRef]

104. Tung, H. Governing Europe's Marine Environment: Europeanization of Regional Seas or Regionalization of EU Policies Book Reviews. J. Common Mkt. Stud. 2016, 54, 1040-1041.

105. Berkowitz, H.; Crowder, L.B.; Brooks, C.M. Organizational Perspectives on Sustainable Ocean Governance: A Multi-Stakeholder, Meta-Organization Model of Collective Action. Mar. Policy 2020, 118, 104026. [CrossRef]

106. Stojanovic, T.; Gee, K. Governance as a Framework to Theorise and Evaluate Marine Planning. Mar. Policy 2020, $120,104115$. [CrossRef]

107. Chang, Y.-C.; Wang, C.; Khan, M.I.; Wang, N. Legal Practices and Challenges in Addressing Climate Change and Its Impact on the Oceans-A Chinese Perspective. Mar. Policy 2020, 111, 103355. [CrossRef]

108. Morgan, J.; Patomäki, H. Planetary Good Governance after the Paris Agreement: The Case for a Global Greenhouse Gas Tax. J. Environ. Manag. 2021, 292, 112753. [CrossRef] [PubMed]

109. Hassanali, K. Improving Ocean and Coastal Governance in Trinidad and Tobago-Moving towards ICZM. Ocean Coast. Manag. 2015, 106, 1-9. [CrossRef]

110. Cho, D.-O. Korea's Oceans Policymaking: Toward Integrated Ocean Management. Coast. Manag. 2012, 40, 183-194. [CrossRef]

111. Zou, K. China's Ocean Policymaking: Practice and Lessons. Coast. Manag. 2012, 40, 145-160. [CrossRef]

112. Gupta, J.; Nilsson, M. Toward a Multi-level Action Framework for Sustainable Development Goals. In Governing through goals: Sustainable Development Goals as Governance Innovation; Biermann, F., Kanie, N., Eds.; MIT Press: Cambridge, MA, USA, 2017; pp. 275-333.

113. Monkelbaan, J. (Ed.) Conclusions: The Integrative Sustainability Governance Framework and Ways Forward. In Governance for the Sustainable Development Goals: Exploring an Integrative Framework of Theories, Tools, and Competencies; Sustainable Development Goals Series; Springer: Singapore, 2019; pp. 193-214, ISBN 9789811304750.

114. Butt, M.J.; Zulfiqar, K.; Chang, Y.-C. The Role of the International Law in Shaping the Governance for Sustainable Development Goals. J. Law Political Sci. 2021, 28, 87-164. [CrossRef]

115. Keyuan, Z. Implementing Marine Environmental Protection Law in China: Progress, Problems and Prospects. Mar. Policy 1999, 23, 207-225. [CrossRef]

116. Mahon, R.; Fanning, L.; McConney, P. Principled Ocean Governance for the Wider Caribbean Region. In Towards Marine EcosystemBased Management in the Wider Caribbean; Mahon, R., Fanning, L., McConney, P., Eds.; Amsterdam University Press: Amsterdam, The Netherlands, 2011; pp. 27-38, ISBN 978-90-8964-242-4.

117. Proelss, A.; Hong, C. Ocean Upwelling and International Law. Ocean Dev. Int. Law 2012, 43, 371-385. [CrossRef]

118. Chang, Y.-C.; Wang, N.; Zhao, Y. The Current Development of the Ocean Governance Mechanism in China. Coast. Manag. 2013, 41, 120-133. [CrossRef]

119. Vidas, D.; Fauchald, O.K.; Jensen, Ø.; Tvedt, M.W. International Law for the Anthropocene? Shifting Perspectives in Regulation of the Oceans, Environment and Genetic Resources. Anthropocene 2015, 9, 1-13. [CrossRef] 
120. Tsamenyi, M.; Kenchington, R. Australian Oceans Policymaking. Coast. Manag. 2012, 40, 119-132. [CrossRef]

121. Chomariyah Oceans Governance: Implementation of the Precautionary Approach to Anticipate in Fisheries Crisis. Proc. Earth Planet. Sci. 2015, 14, 94-100. [CrossRef]

122. Bauerlein, P.C. The United Nations Convention on the Law of the Sea \& (and) US Ocean Environmental Practice: Are We Complying with International Law. Loyola Los Angeles Int. Comp. Law J. 1994, 17, 899.

123. Chircop, A. Regional Cooperation in Marine Environmental Protection in the South China Sea: A Reflection on New Directions for Marine Conservation. Ocean Dev. Int. Law 2010, 41, 334-356. [CrossRef]

124. Ellsworth, J.P.; Hildebrand, L.P.; Glover, E.A. Canada's Atlantic Coastal Action Program: A Community-Based Approach to Collective Governance. Ocean Coast. Manag. 1997, 36, 121-142. [CrossRef]

125. Juda, L. Changing National Approaches to Ocean Governance: The United States, Canada, and Australia. Ocean Dev. Int. Law 2003, 34, 161-187. [CrossRef]

126. Environment and Climate Change, Canada. Protection of Marine Environment from Land-Based Sources of Pollution; Government of Canada, Official: Quebec, QC, Canada, 2009. Available online: https:/ /www.canada.ca/en/environment-climate-change/ services / canadian-environmental-protection-act-registry / general-information/fact-sheets / protection-marine-environmentland-based.html (accessed on 3 September 2021).

127. Environment and Climate Change, Canada. Pollution and Waste Management; Government of Canada, Official: Quebec, QC, Canada, 2017. Available online: https:/ / www.canada.ca/en/services/environment/pollution-waste-management.html (accessed on 3 September 2021).

128. Barnes-Dabban, H.; van Koppen, C.S.A.; van Tatenhove, J.P.M. Regional Convergence in Environmental Policy Arrangements: A Transformation towards Regional Environmental Governance for West and Central African Ports? Ocean Coast. Manag. 2018, 163, 151-161. [CrossRef]

129. Coenen, F. Local Agenda 21: 'Meaningful and Effective' Participation? In Public Participation and Better Environmental Decisions: The Promise and Limits of Participatory Processes for the Quality of Environmentally Related Decision-Making; Coenen, F.H.J.M., Ed.; Springer: Dordrecht, The Netherlands, 2009; pp. 165-182, ISBN 978-1-4020-9325-8.

130. Pinto, M.C.W. Participation and Compliance in International Law Ocean Governance. Ocean Y. B. 2004, 18, 220-245. [CrossRef]

131. Stephenson, R.L.; Hobday, A.J.; Allison, E.H.; Armitage, D.; Brooks, K.; Bundy, A.; Cvitanovic, C.; Dickey-Collas, M.; de Miranda Grilli, N.; Gomez, C.; et al. The Quilt of Sustainable Ocean Governance: Patterns for Practitioners. Front. Mar. Sci. 2021, 8, 63054. [CrossRef]

132. Gillespie, A. Transparency in International Environmental Law: A Case Study of the International Whaling Commission. Geo. Int'l Envtl. L. Rev. 2001, 14, 333-348.

133. Maritime Safety Authority of Fiji Government. Marine (Pollution Prevention and Management) Regulations 2014; Vol. Legal Notice No. 112. Suva, Fiji Islands. Available online: https:/ /www.msaf.com.fj/wp-content/uploads/2020/12/33.-Marine_Pollution_ Prevention_Management_Regulations_2014_1-min.pdf (accessed on 3 September 2021).

134. Sloan, J.; Samuela, E. Fiji Marine Pollution Law Series-Industrial Pollution. Available online: https://www.sas.com.fj/oceanlaw-bulletins / fiji-marine-pollution-law-series-industrial-pollution (accessed on 3 September 2021).

135. Chandra, A. A Deliberate Inclusive Policy (DIP) Approach for Coastal Resources Governance: A Fijian Perspective. Coast. Manag. 2011, 39, 175-197. [CrossRef]

136. Secretariat Report. Clean Seas for a Cleaner Pacific to Help Save Our Lifeblood Pacific Environment: Waste Management and Pollution Control; 2017; Secretariat of the Pacific Regional Environmental Programme. Available online: https://www.sprep.org/news/ clean-seas-cleaner-pacific-help-save-our-lifeblood (accessed on 3 September 2021).

137. Olawuyi, D.S. Harmonizing International Trade and Climate Change Institutions: Legal and Theoretical Basis for Systemic Integration. Law Dev. Rev. 2014, 7, 107-129. [CrossRef]

138. Ehlers, P. Blue Growth and Ocean Governance-How to Balance the Use and the Protection of the Seas. WMU J. Marit Affairs 2016, 15, 187-203. [CrossRef]

139. Merrie, A.; Dunn, D.C.; Metian, M.; Boustany, A.M.; Takei, Y.; Elferink, A.O.; Ota, Y.; Christensen, V.; Halpin, P.N.; Österblom, H. An Ocean of Surprises-Trends in Human Use, Unexpected Dynamics and Governance Challenges in Areas beyond National Jurisdiction. Glob. Environ. Change 2014, 27, 19-31. [CrossRef]

140. Vince, J.; Brierley, E.; Stevenson, S.; Dunstan, P. Ocean Governance in the South Pacific Region: Progress and Plans for Action. Mar. Policy 2017, 79, 40-45. [CrossRef]

141. Bigagli, E. The International Legal Framework for the Management of the Global Oceans Social-Ecological System. Mar. Policy 2016, 68, 155-164. [CrossRef]

142. Kirk, E.A. The Ecosystem Approach and the Search for An Objective and Content for the Concept of Holistic Ocean Governance. Ocean Dev. Int. Law 2015, 46, 33-49. [CrossRef]

143. Zervaki, A. The Ecosystem Approach and Public Engagement in Ocean Governance: The Case of Maritime Spatial Planning. In The Ecosystem Approach in Ocean Planning and Governance; Langlet, D., Rayfuse, R., Eds.; Brill Nijhoff: Leiden, The Netherlands, 2018; pp. 223-255.

144. Wright, G. Marine Governance in an Industrialised Ocean: A Case Study of the Emerging Marine Renewable Energy Industry. Mar. Policy 2015, 52, 77-84. [CrossRef] 
145. VanderZwaag, D.L.; Oral, N. Editors' Introduction-International Ocean Governance in the 21st Century International Ocean Governance In the 21st Century Perspectives from the IUCN Commission on Environmental Law's Specialist Group on Oceans, Coasts and Coral Reefs. Int. J. Mar. Coast. L. 2008, 23, 393-398. [CrossRef]

146. Terashima, H. Japan's Ocean Policymaking. Coast. Manag. 2012, 40, 172-182. [CrossRef]

147. Kim, S.G. The Impact of Institutional Arrangement on Ocean Governance: International Trends and the Case of Korea. Ocean Coast. Manag. 2012, 64, 47-55. [CrossRef]

148. Keen, M.R.; Schwarz, A.-M.; Wini-Simeon, L. Towards Defining the Blue Economy: Practical Lessons from Pacific Ocean Governance. Mar. Policy 2018, 88, 333-341. [CrossRef]

149. Harrould-Kolieb, E.R. Framing Ocean Acidification to Mobilise Action under Multilateral Environmental Agreements. Environ. Sci. Policy 2020, 104, 129-135. [CrossRef]

150. Iqbal, K.M.J.; Khan, M.I. Climate Governance: Implementing Water Sector Adaptation Strategies in Pakistan. Policy Perspect. 2018, 15, 139-155. [CrossRef]

151. Khan, R.S. Pakistan Passes Climate Change Act, Reviving Hopes and Skepticism. Available online: https:/ /www.reuters.com/ article/us-pakistan-climatechange-lawmaking-idUSKBN16V19N (accessed on 3 September 2021).

152. Butt, M.J.; Chang, Y.C.; Zulfiqar, K. A Comparative Analysis of the Environmental Policies in China and Pakistan: Developing a Legal Regime for Sustainable China-Pakistan Economic Corridor (CPEC) under the Belt and Road Initiative (BRI). IPRI J. 2021, 21, 83-122. [CrossRef]

153. Harrould-Kolieb, E.R.; Hoegh-Guldberg, O. A Governing Framework for International Ocean Acidification Policy. Mar. Policy 2019, 102, 10-20. [CrossRef]

154. Chang, Y.-C.; Shi, X. Rule of Law and the Marine Environmental Networks: Conference Report. Mar. Policy 2020, $113,103778$. [CrossRef]

155. Newton, J.; Feely, R.; Jewett, E.; Williamson, P.; Mathis, J. Global Ocean Acidification Observing Network: Requirements and Governance Plan, 2nd ed.; 2015. Available online: https:/ /www.iaea.org/sites/default/files/18/06/goa-on-second-edition-2015 .pdf (accessed on 3 September 2021).

156. Richards, R.G.; Davidson, A.T.; Meynecke, J.-O.; Beattie, K.; Hernaman, V.; Lynam, T.; van Putten, I.E. Effects and Mitigations of Ocean Acidification on Wild and Aquaculture Scallop and Prawn Fisheries in Queensland, Australia. Fish. Res. 2015, 161, 42-56. [CrossRef]

157. Valentine, S.V. Enhancing Climate Change Mitigation Efforts through Sino-American Collaboration. Chin. J. Int. Politics 2013, 6, 159-182. [CrossRef]

158. Cole, D.H. Advantages of a Polycentric Approach to Climate Change Policy. Nat. Clim Change 2015, 5, 114-118. [CrossRef]

159. Bayliss-Brown, G.; Gerhardinger, L.C.; Starger, C. Networked Knowledge to Action in Support of Ocean Sustainability. Coast. Manag. 2020, 48, 235-237. [CrossRef]

160. Knecht, R.W. Essay: Emerging International Goals and Principles and Their Influence on National Ocean Governance. Coast. Manag. 1994, 22, 177-182. [CrossRef]

161. Ekstrom, J.A.; Young, O.R.; Gaines, S.D.; Gordon, M.; McCay, B.J. A Tool to Navigate Overlaps in Fragmented Ocean Governance. Mar. Policy 2009, 33, 532-535. [CrossRef]

162. Håkon Hoel, A.; Sydnes, A.K.; Ebbin, S.A. Ocean Governance and Institutional Change. In A Sea Change: The Exclusive Economic Zone and Governance Institutions for Living Marine Resources; Ebbin, S.A., Håkon Hoel, A., Sydnes, A.K., Eds.; Springer: Dordrecht, The Netherlands, 2005; pp. 3-16, ISBN 978-1-4020-3133-5.

163. Gulseven, O. Measuring Achievements towards SDG 14, Life below Water, in the United Arab Emirates. Mar. Policy 2020, 117, 103972. [CrossRef]

164. Tiller, R.; Arenas, F.; Galdies, C.; Leitão, F.; Malej, A.; Romera, B.M.; Solidoro, C.; Stojanov, R.; Turk, V.; Guerra, R. Who Cares about Ocean Acidification in the Plasticene? Ocean Coast. Manag. 2019, 174, 170-180. [CrossRef]

165. Russel, D.J.; den Uyl, R.M.; de Vito, L. Understanding Policy Integration in the EU-Insights from a Multi-Level Lens on Climate Adaptation and the EU's Coastal and Marine Policy. Environ. Sci. Policy 2018, 82, 44-51. [CrossRef]

166. Marian, I. Developing Effective Ocean Governance. Geopolit. Hist. Int. Relat. 2012, 4, 101-106. [CrossRef]

167. Beisheim, M.; Simon, N. Multistakeholder Partnerships for the SDGs: Actors' Views on UN Metagovernance. Glob. Gov. A Rev. Multilater. Int. Organ. 2018, 24, 497-515. [CrossRef]

168. Lwabukuna, O.K. International Rule of Law and Development: Underpinnings of the MDGs and the Post-2015 SDGs Agenda. J. Peacebuilding Dev. 2016, 11, 89-94. [CrossRef]

169. Hershman, M.J.; Russell, C.W. Regional Ocean Governance in the United States: Concept and Realty. Duke Envtl. L. Pol'y F. 2005, 16, 227.

170. Johnson, D.; Froján, C.B.; Bax, N.; Dunstan, P.; Woolley, S.; Halpin, P.; Dunn, D.; Hazin, C.; Dias, M.; Davies, T.; et al. The Global Ocean Biodiversity Initiative: Promoting Scientific Support for Global Ocean Governance. Aquat. Conserv. Mar. Freshw. Ecosyst. 2019, 29, 162-169. [CrossRef]

171. Yadav, S.S.; Gjerde, K.M. The Ocean, Climate Change and Resilience: Making Ocean Areas beyond National Jurisdiction More Resilient to Climate Change and Other Anthropogenic Activities. Mar. Policy 2020, 122, 104184. [CrossRef]

172. Akaso, A.A. Oceans Policy as a Sustainable Tool for the Regulation of the Marine Environment. Int'l J. Adv. Leg. Stud. Gov. 2012, 3, 71-77. 